\title{
Predicting the Uniaxial Compressive Strength of a Limestone Exposed to High Temperatures by Point Load and Leeb Rebound Hardness Testing
}

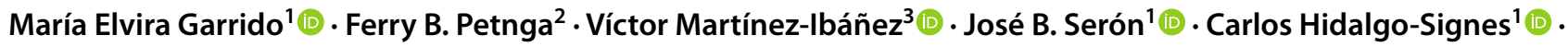 \\ Roberto Tomás ${ }^{4}[$
}

Received: 16 March 2021 / Accepted: 13 September 2021 / Published online: 12 October 2021

(c) The Author(s) 2021

\begin{abstract}
The effect of exposure to high temperature on rock strength is a topic of interest in many engineering fields. In general, rock strength is known to decrease as temperature increases. The most common test used to evaluate the rock strength is the uniaxial compressive strength test (UCS). It can only be carried out in laboratory and presents some limitations in terms of the number, type and preparation of the samples. Such constrains are more evident in case of rocks from historical monuments affected by a fire, where the availability of samples is limited. There are alternatives for an indirect determination of UCS, such as the point load test (PLT), or non-destructive tests such as the Schmidt's hammer, that can also be performed in situ. The aims of this research are: (i) measuring the effect of high temperatures and cooling methods on the strength and hardness of a limestone named Pedra de Borriol widely used in several historic buildings on the E of Spain, and (ii) studying the possibility of indirectly obtaining UCS by means of PLT and Leeb hardness tests (LHT), using Equotip type D. Limestone samples were heated to 105 (standard conditions), 200, 300, 400, 500, 600, 700, 800 and $900{ }^{\circ} \mathrm{C}$ and cooled slowly (in air) and quickly (immersed in water). After that, UCS, PLT and LHT tests were performed to evaluate the changes as temperature increases. Results show decreases over $90 \%$ in UCS, of between 50 and 70\% in PLT index and smaller than $60 \%$ in LHT index. Insignificant differences between cooling methods were observed, although slowly cooled samples provide slightly higher values than quickly cooled ones. The results indicate that LHT can be used to indirectly estimate UCS, providing an acceptable prediction. Research on correlating strength parameters in rocks after thermally treated is still scarce. This research novelty provides correlations to predict UCS in historic buildings if affected by a fire, from PLT and non-destructive methods such as LHT whose determination is quicker and easier.
\end{abstract}

Keywords Limestone $\cdot$ Strength $\cdot$ Hardness $\cdot$ High temperatures $\cdot$ Uniaxial compression strength $\cdot$ Point load test $\cdot$ Hardness Leeb-D value $\cdot$ Historic building

María Elvira Garrido

egarrido@trr.upv.es

Ferry B. Petnga

ferryblondo@gmail.com

Víctor Martínez-Ibáñez

vicmarib@trr.upv.es

José B. Serón

jbseron@trr.upv.es

Carlos Hidalgo-Signes

chidalgo@trr.upv.es

Roberto Tomás

roberto.tomas@ua.es
1 Department of Geotechnical and Geological Engineering, Universitat Politècnica de València, 46071 Valencia, Spain

2 Facoltà di Ingegneria, Università Politecnica delle Marche, Ancona, Italy

3 Department of Construction Engineering and Civil Engineering Projects, Universitat Politècnica de València, 46071 Valencia, Spain

4 Departamento de Ingeniería Civil, Escuela Politécnica Superior de Alicante, Universidad de Alicante, P.O. Box 99, 03080 Alicante, Spain 


\section{Introduction}

Investigations on fire events in historic buildings contribute to a better understanding of the consequences of high temperatures on stone-made structures (Chen et al. 2012; Ioannou et al. 2017; Zhang et al. 2016). Most historical heritage around the world was built using stone, and reported incidents demonstrate that fires seriously damage or even destroy such buildings (e.g. Leon Cathedral 1966; Windsor Castle 1992; National Museum of Brazil 2018; Notre Dame Cathedral 2019; Nantes Cathedral 2020; Plasencia Church 2020). Even if such events are rare, they usually generate great social alarm, and cause major economic costs, and important losses of heritage. Given the historical, cultural and social value of our stone-built heritage, understanding the effects of high temperatures and the cooling methods is crucial for the prevention and maintenance of these buildings.

Thermal stresses appear in rocks when heated, giving rise to numerous inter- and intra-granular microcracks (Jansen et al. 1993) which gradually expand and lead to a weakening and progressive decay in rock integrity (David et al. 1999; Keshavarz et al. 2010). Thermal damage on rocks can be attributed to differential thermal expansion (Rosengren and Jaenger 1968) and/or thermal oxidation processes of the mineral components, as well as initial micro-fissuring in the intact rock (Martínez-Ibáñez et al. 2020a, b).

Consequently, to understand the effects of such decay is of paramount importance for the subsequent tasks of rehabilitation and reconstruction of these monuments. Scientific literature has reported that temperature leads to important changes in the materials and every rock exhibits a different behaviour as a function of its composition, water absorption, porosity, density, etc. Furthermore, it is widely acknowledged that mechanical properties are directly related to physical properties (Meulenkamp and Alvarez Grima 1999; Verwaal and Mulder 1993).

Strength is the most important mechanical property of rocks that is usually determined by the uniaxial compressive strength (UCS) test. UCS tests require numerous samples, and these must be accurately extracted and transported to the laboratory to be prepared with the dimensions required by standards. Alternatively, UCS can be determined by means of other laboratory tests such as the point load test (PLT) (Galvan et al. 2014; Şahin et al. 2020), Schmidt hardness test (SH) (Aydin 2009; Sabatakakis et al. 2008), Leeb rebound hardness test (LHT) (Corkum et al. 2018; Meulenkamp and Alvarez Grima 1999; Verwaal and Mulder 1993; Yilmaz 2013) and the needle penetration test (NPT) (Rabat et al. 2020) which provide quicker, cheaper and sufficiently reliable results.
The estimation of rock matrix properties using specific empirical relationship is widely and commonly used in rock mechanics. These correlations can provide a fast and cost-effective estimation of parameters using simple tests. Numerous authors have presented correlations between PLT and HLD, with UCS-derived parameters (Bieniawski 1975; Broch and Franklin 1972; Deere and Miller 1965; Şahin et al. 2020), but little research is available on strength prediction for rocks exposed to high temperatures. Predictors in most cases are physical properties such as mineral grain characteristics (Armaghani et al. 2016; Gokceoglu and Zorlu 2004; Vagnon et al. 2021), density, porosity and wave velocity (Martínez-Ibáñez et al. 2021a, b; Singh et al. 2017; Singh et al. 2001; Sonmez et al. 2006; Sonmez et al. 2004; Yesiloglu-Gultekin et al. 2013; Zorlu et al. 2008). Few studies consider the prediction of UCS by means of the relationship with indexes obtained using the mentioned tests, particularly on thermally treated rocks.

PLT is suitable for determining rock strength on regular and small irregular samples, and is quicker (when including the time required for sample preparation) and cheaper than the UCS test. Another advantage is that it can be performed both in the field and in the laboratory. On the other hand, it is not suitable for very hard rocks when obtaining the results is laborious and time consuming.

Furthermore, it is a destructive test and the strength value is obtained indirectly. The relationship between UCS and PLT index, $I_{\mathrm{s}(50)}$, is generally expressed as follows (Diamantis et al. 2009; Kahraman et al. 2005; Sabatakakis et al. 2008):

$\mathrm{UCS}=\beta \times I_{\mathrm{s}(50)}$,

where $\beta$ coefficients vary from 13.5 to 30.0 , depending on the type of rock (Table 1).

As already mentioned, the NPT is used to indirectly determine rock strength. Its advantages are that it requires neither special preparation of specimens nor heavy and expensive equipment, it can be used in the field or the laboratory, tests and the calculation of results can be quickly performed, and it is non-destructive (essential to estimate rock strength in protected natural structures or historical or heritage buildings). NPT is very sensitive to UCS changes and is particularly suitable for soft rocks (with UCS less than $20 \mathrm{MPa}$ ) (Rabat et al. 2020).

$\mathrm{SH}$ was originally conceived to determine strength of concrete, and was quickly adopted for obtaining the surface hardness and indirect determination of UCS on rocks (Barton and Choubey 1977; Deere and Miller 1965; Kahraman et al. 2005; O'Rourke 1989; Ylmaz and Sendr 2002). It exhibits similar advantages as PLT or NPT, although obtaining the results is easier as it is a non-destructive test (Rabat et al. 2020). SH also presents some drawbacks as it is highly 
Table 1 Values for $\beta$ coefficient that relates UCS and PLT index $\left[I_{\mathrm{s}(50)}\right]$ reported in previous studies

\begin{tabular}{llll}
\hline References & $\beta$ & $R^{2}$ & Description \\
\hline Broch and Franklin (1972) & 23.7 & - & Different rock types \\
Bieniawski (1975) & 23.0 & - & Different rock types \\
Hassani et al. (1980) & 29.0 & - & Sedimentary rocks \\
O'Rourke (1989) & 30.0 & - & Sedimentary rocks \\
Singh and Singh (1993) & 23.4 & 0.64 & Quartzite rock samples \\
Tugrul and Zarif (1999) & 15.3 & 0.96 & Granitic rock samples \\
Sulukcu and Ulusay (2001) & 15.3 & 0.69 & Different rock types \\
Thuro et al. (2001) & 18.7 & 0.60 & Different rock types \\
Basu and Aydin (2006) & 18.0 & 0.97 & Granitic rock samples \\
Diamantis et al. (2009) & 19.8 & 0.74 & Serpentinite rock \\
Galvan et al. (2014) & 13.5 & 0.87 & Limestone \\
Kohno and Maeda (2012) & 16.4 & 0.85 & Different rock samples \\
Şahin et al. (2020) & 12.8 & 0.83 & Different rock types \\
Rabat et al. (2020) & 14.3 & 0.98 & Siltstones \\
\hline
\end{tabular}

sensitive to the edge effect and requires a sample size greater than $1000 \mathrm{~cm}^{3}$ to obtain reliable results (Viles et al. 2011). However, the main disadvantage of SH is that the hammer exerts a high impact energy that could endanger the integrity of fire-weakened rocks.

Consequently, LHT can be appropriate due to its relatively low impact energy. LHT is a dynamic rebound hardness test method similar to SH. The Leeb hardness test (LHT with test value of LD) is a rebound hardness test, originally developed for metals. The tests can be carried out rapidly, conveniently and non-destructively on core and block samples or on rock outcrops. This makes the relatively small LHT device convenient for field tests.

ASTM standard determines the application of LHT for steel products (ASTM Standard A956-12, 2012). However, this standard is not applicable for testing rock materials, and no ISRM Suggested Method exists. Several authors (Aoki and Matsukura 2008; Corkum et al. 2018; Kompatscher 2004; Meulenkamp and Alvarez Grima 1999; Verwaal and Mulder 1993; Viles et al. 2011) have studied the use of LHT in rock materials and suggested testing methods and equipment. Equotip is currently the most frequently used portable hardness tester based on the dynamic rebound method (Kompatscher 2004) that enables the determination of the hardness Leeb index (designated as HLD when the most common type ' $\mathrm{D}$ ' impact device is used). This test has been correlated with the Uniaxial Compressive Strength of intact rock by various authors. As with $\mathrm{SH}$, it has shown to be valid for the indirect determination of UCS on rocks. Although some authors proposed exponential equations, the relationship between UCS and HLD is generally expressed by means of potential relationships:
$\mathrm{UCS}=\alpha \times 10^{\eta} \times \mathrm{HLD}^{\beta}$,

where $\alpha, \eta$ and $\beta$ are constants that mainly depend on the rock type. Table 2 shows previous correlations between UCS and HLD found in the literature for various intact rocks, although no specific correlations for thermally treated rocks have been published to this day.

LHT is a convenient and rapid hardness test. It has advantages similar to SH test, such as being easy to be performed in the field and providing a large number of measurements on a relatively small surface due to its small size. However, this test also has additional benefits in comparison with $\mathrm{SH}$, such as its insensitiveness to block size, border effects and moisture levels (Corkum et al. 2018), which makes LHT an ideal non-destructive method to evaluate the hardness of rocks. It is especially appropriate in protected heritage buildings, and monuments and constructions made of natural stone due to its lower impact energy. Existing research point to LHT as a useful, repeatable and quantifiable method for field estimation of rock strength. Therefore, this test could be very useful to assess temperature-induced changes on rock matrix and to indirectly estimate rock strength properties.

The aim of this research is to evaluate the influence of temperature on: (a) strength of the 'Pedra de Borriol' limestone (a natural stone widely used in the cultural heritage buildings in Eastern Spain) using both destructive tests UCS and PLT; and (b) the hardness of the rock by means of the LHT non-destructive technique. In addition, correlations between the parameters obtained by the different tests will enable a verification of the suitability of LHT and PLT to indirectly obtain the UCS of the studied limestone if affected by high temperatures. It is worth noting that research on correlating these properties on rock samples when exposed to high temperatures is scarce.

In this research, BL samples were heated to different target temperatures from 105 to $900{ }^{\circ} \mathrm{C}$ to cover the whole range of temperatures that could develop during a fire (Brotóns et al. 2014). Subsequently, they were cooled using two different methods: a slow rate (in air to simulate natural fire extinction) and at a fast rate (by water immersion to simulate the intervention of firefighters). UCS tests were then performed to study strength decay with temperature, and these were compared with PLT and LHT results to propose new correlations.

\section{Materials and Methods}

\subsection{Rock Description and Sampling}

Samples from 'Pedra de Borriol' limestone were extracted from a quarry in Borriol (Castellon, Eastern Spain). The studied natural stone has been used in several historic 
Table 2 Empirical correlations in the literature regarding the determination of UCS by HLD

\begin{tabular}{|c|c|c|c|}
\hline References & Best-fit equation & $\mathrm{R}^{2}$ & Description \\
\hline Verwaal and Mulder (1993) & $\mathrm{UCS}=5.0 \times 10^{-8} \times \mathrm{HLD}^{3.35}$ & 0.85 & Different limestones \\
\hline $\begin{array}{l}\text { Meulenkamp and Alvarez Grima } \\
\text { (1999) }\end{array}$ & $\mathrm{UCS}=1.8 \times 10^{-9} \times \mathrm{HLD}^{3.80}$ & 0.81 & Different rock types \\
\hline Aoki and Matsukara (2008) & $\mathrm{UCS}=8.0 \times 10^{-6} \times \mathrm{HLD}^{2.50}$ & 0.77 & Different rock types \\
\hline Corkum et al. (2018) & $\mathrm{UCS}=6.7 \times 10^{-7} \times \mathrm{HLD}^{2.91}$ & 0.71 & Sedimentary rocks \\
\hline Gomez-Heras et al. (2020) & $\mathrm{UCS}=1.0 \times 10^{-5.6} \times \mathrm{HLD}^{2.75}$ & 0.96 & Carbonate samples \\
\hline Corkum et al. (2018) & $\mathrm{UCS}=3.1335 \times e^{0.0051 \times \mathrm{HLD}}$ & 0.67 & Sedimentary rocks \\
\hline Yüksek (2019) & $\mathrm{UCS}=2.3559 \times e^{0.0044 \times \mathrm{HLD}}$ & 0.81 & Tuffs (volcanic rocks) \\
\hline
\end{tabular}

UCS (in MPa) and HLD in Leeb-D value

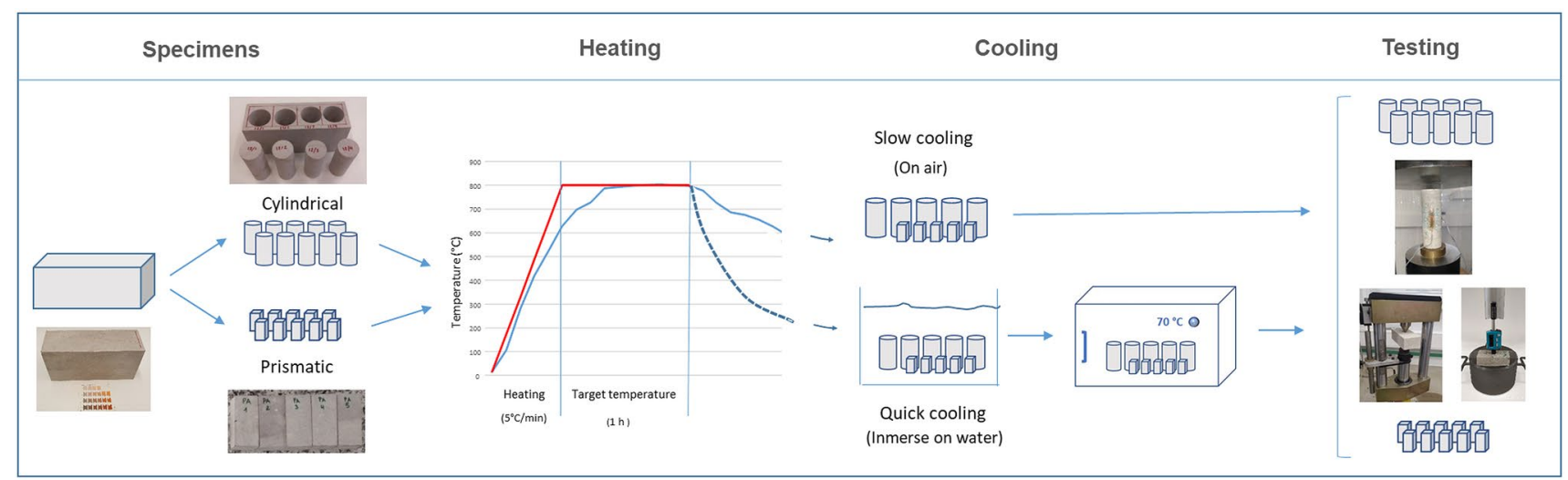

Fig. 1 Scheme of the process of preparation, heating, cooling and testing of samples

buildings and infrastructures in Castellon and Valencia since the seventeenth century. It is a low-porosity Cretaceous rock from the 'Caliza de Benasal' formation, and mainly composed of calcite $(75-85 \%)$ and dolomite (15-20\%) with traces of quartz, illite, goethite and hematite (Ovejero et al. 2005).

The samples tested in this research were obtained from regular blocks measuring $300 \times 140 \times 100 \mathrm{~mm}$ that were brought from the quarry (Fig. 1). Before drilling the samples from the prismatic blocks, ultrasonic P-wave velocity tests were carried out in three orthogonal directions to evaluate anisotropy. Complementarily, uniaxial compressive strength tests were carried out on cylindrical specimens extracted from prismatic blocks using a core-drilling machine, in two orthogonal directions, parallel and perpendicular to bedding. The results indicate that Borriol Limestone is an almost isotropic rock since both the wave velocity anisotropy index $\left(I_{\mathrm{Vp}}\right)$ and the strength anisotropy index $\left(I_{\sigma \mathrm{\sigma c}}\right)$ are close to 1 (Saroglou and Tsiambaos 2007).

A total of 85 cylindrical samples were drilled from the above described rectangular blocks with a diameter of $55 \pm 1 \mathrm{~mm}$ (i.e. diameter similar to NX core size, $54 \mathrm{~mm}$ ) and a height of $140 \pm 1 \mathrm{~mm}$ (i.e. height-to-diameter ratio greater than 2.5 ). Similarly, 85 prismatic samples were prepared with a circular saw. The approximate dimensions of these samples were $97 \times 47 \times 30 \mathrm{~mm}$ (Fig. 1). The prismatic specimens were identified according to the target temperature and cooling method. They were cut from the same blocks where the cylindrical samples for UCS tests were extracted, and it was assured that the surface of the samples was flat, clean, smooth and dry. It is worth noting that the prismatic and cylindrical samples were obtained with the main axis perpendicular to bedding.

The tests were developed according to the suggested methods of International Society for Rock Mechanics.

Specimens were dried in an oven at $70 \pm 5{ }^{\circ} \mathrm{C}$ to remove moisture. Diameters and lengths were measured in three different sections for all samples to calculate the sample volume for the determination of open and total porosity, as well as dry density (Franklin 1979).

\subsection{Heating and Cooling Process}

A total of five cylindrical and five prismatic samples were dried at $105^{\circ} \mathrm{C}$ and then UCS, PLT and LHT tests were performed according ISRM suggested methods. The obtained results were considered as standardised reference values. The remaining samples were divided into groups of ten units 
and heated at temperatures of 200, 300, 400, 500, 600, 700, 800 and $900{ }^{\circ} \mathrm{C}$ (Fig. 1).

Heat treatments were performed inside a furnace which can reach maximum temperatures of $1300{ }^{\circ} \mathrm{C}$. Control of temperature inside the furnace was performed by means of $\mathrm{K}$ - and N-type mineral insulated thermocouples connected to a data acquisition module PicoLog TC08-Pico Technology. A temperature gradient of $5^{\circ} \mathrm{C} / \mathrm{min}$ was applied. This value was chosen because it is the most commonly used in the published literature (Ozguven and Ozcelik 2014; Sirdesai et al. 2017; Yang et al. 2019) and because for such a small heating rate the influence of the heating gradient can be neglected (Garrido et al. 2020; Wang et al. 2019). After having reached the target temperature, it was maintained for $1 \mathrm{~h}$ (Brotóns et al. 2013; Martínez-Ibáñez et al. 2020a). Subsequently, the samples heated to temperatures greater than $300{ }^{\circ} \mathrm{C}$ were cooled at a slow rate inside the furnace until $300^{\circ} \mathrm{C}$ to be able to manipulate them safely (Brotóns et al. 2013; Martínez-Ibáñez et al. 2020b).

Two different cooling methods were then applied (Fig. 1): slow rate (i.e. air-cooled 'A' until reaching room temperature); or at a quick rate (i.e. immersed in water ' $W$ ' for $10 \mathrm{~min}$ and then dried in an oven at $70^{\circ} \mathrm{C}$ ). The first method simulates the situation in which a fire burns out naturally without any intervention, and the second reproduces the situation in which it is extinguished with water by the fire brigade (Tomás et al. 2021).

Finally, UCS, PLT and LHT tests were carried out $24 \mathrm{~h}$ later at room temperature $\left(25^{\circ} \mathrm{C}\right)$ to evaluate temperatureinduced changes (Fig. 1).

\subsection{Laboratory Tests}

UCS tests were carried out on cylindrical specimens (Fig. 1a) according to the method suggested by the ISRM (Bieniawski and Bernede 1979) A four-column hydraulic press machine with a capacity of $2 \mathrm{MN}$ was used, and a compression rate of $0.5 \mathrm{MPa} / \mathrm{s}$ was applied until the ultimate load. A total of 85 cylindrical specimens were tested, 5 for standard conditions (Bieniawski and Bernede 1979) and 10 for each temperature from 200 to $900{ }^{\circ} \mathrm{C}$, as well as 5 for each cooling method (i.e. quick and slow cooling).

In addition, PLT and LHT tests were carried out on 85 prismatic specimens. Ten specimens were tested for each temperature (five for each cooling method) and five more were chosen as pattern samples (PA). Point load tests were performed following the method suggested by the ISRM (Bieniawski 1975) (Fig. 1). The samples were loaded diametrically until failure occurred and divided the prismatic specimens into two fragments. After that, the point load strength index, $I_{\mathrm{s}}$, was calculated. A size correction was applied to obtain the $I_{\mathrm{s}(50)}$ index because the samples used had sizes that differed from the $50 \mathrm{~mm}$ standard diameter.
Finally, Leeb rebound hardness tests were carried out on the surfaces of two fragments resulting from each PLT test. For that purpose an Equotip Piccolo 2 type ' $D$ ' was used, that applies an impact energy of $11 \mathrm{Nmm}$ that internally transforms the impact and rebound velocities into the hardness value $\mathrm{L}$.

Before carrying out this test, aspects such as the volume of each specimen (at least $V<90 \mathrm{~cm}^{3}$ for block or irregular block specimens), the smoothness and cleaning of the cut rock surface, have been taken into account (Corkum et al. 2018). The impacts have been spaced in an area of 25-50 mm diameter on each specimen.

Corkum et al. (2018) recommends a number of 12 impacts for typical cases, or 20 impacts for particularly sensitive projects or when rocks exhibit high local variability. In this study, a total of ten measurements were registered on each of two fragments resulting from the PLT test and the Leeb hardness index was obtained as a trimmed mean. The $L$-value, known as Leeb hardness (HL), is calculated as follows:

$L=\frac{v_{\mathrm{r}}}{v_{\mathrm{i}}} \times 1000$,

where $v_{\mathrm{r}}$ is the rebound velocity and $v_{\mathrm{i}}$ is the impact velocity of the impact body.

The peak induction voltages are proportional to the impact and rebound velocities and are measured at a defined position from the test surface. When both velocities are equal, it means a fully elastic rebound, and then $L$ is equal to 1000 (Kompatscher 2004). HL is lower with decreasing material hardness. The symbol for the hardness scale (HL) is followed by a character representing the type of impact device used (HLD in the current study).

\section{Results}

\subsection{Pedra de Borriol Reference Values}

The mean open and total porosities of this limestone are $1.0 \pm 0.2$ and $2.4 \pm 0.4 \%$, respectively. These values are low, revealing that only a low percentage of the total porosity of the rock is due to open pores (i.e. $41.6 \%$ ). The average dry densities for cylindrical and prismatic samples are $2.662 \pm 12$ and $2.669 \pm 21 \mathrm{~g} \mathrm{~cm}^{-3}$, respectively. The mean UCS is $176.8 \pm 6.7 \mathrm{MPa}$ which is classified as a 'very strong' rock (Bieniawski 1974). The mean point load test index is $5.86 \pm 0.38 \mathrm{MPa}$ which corresponds to 'very high' according to the ISRM (Barton 1979). The Leeb rebound hardness test index is $677 \pm 23$. 


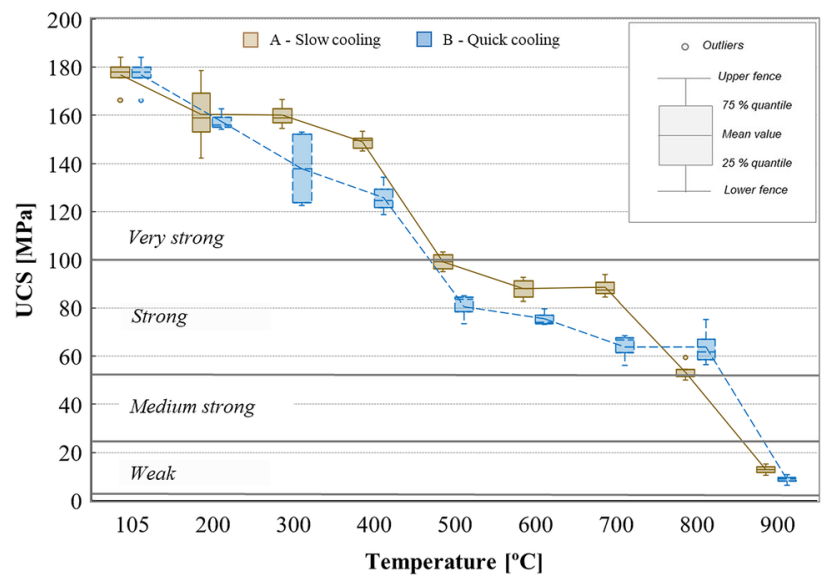

Fig. 2 Uniaxial compressive strength after heating treatment for different temperatures. The intervals of strength are defined according to Bieniawski (1974)

\subsection{Uniaxial Compressive Strength}

Figure 2 shows the changes in UCS for both heating treatments, i.e. for slowly and quickly cooled samples. It is worth noting that some of the samples exposed to $900{ }^{\circ} \mathrm{C}$ and quickly cooled disaggregated and broke during water immersion, so this plot only includes the values of those samples that maintained integrity after the cooling process (a total of three in five).

As can be seen, UCS was adversely affected by the heating process, as previously reported by different authors (Brotóns et al. 2013; Wu et al. 2013; Zhang et al. 2009). This property decreased as the target temperature increased. It was almost null at $900{ }^{\circ} \mathrm{C}$ because it decreased to 92.7 and 95.0\% for slow- and quick-cooled samples, respectively, at this temperature. The rate of decrease was similar for both cooling methods and UCS values were slightly lower for quick-cooled samples (i.e. nearly $10 \%$ lower for quick than for slow cooling). $800{ }^{\circ} \mathrm{C}$ is the only target temperature where the UCS values from slow cooling are higher than quick cooling (Fig. 2).

The results showed a low dispersion with exceptions for those samples slowly cooled at $200{ }^{\circ} \mathrm{C}$ and quick-cooled samples at $300^{\circ} \mathrm{C}$. It is observed that beyond the target temperature of $400{ }^{\circ} \mathrm{C}$ there is a strong decrease in the UCS values for both cooling methods and this is repeated beyond $700{ }^{\circ} \mathrm{C}$ (only for air-cooled samples). Samples tested up to $400^{\circ} \mathrm{C}$ can be identified as very strong rocks and from this temperature up to $800{ }^{\circ} \mathrm{C}$ they can be identified as strong rocks. Samples exposed to $900{ }^{\circ} \mathrm{C}$ have become weak rocks.

The greatest differences in the UCS between cooling methods were observed at 300,400 and $700{ }^{\circ} \mathrm{C}$ and reached above $13 \%$. Differences hardly reached $6 \%$ for the rest of temperatures.

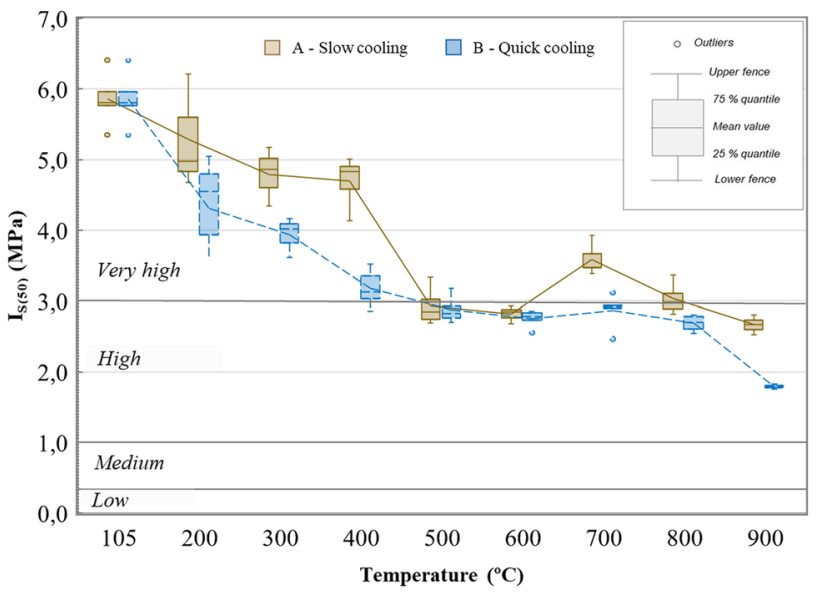

Fig. 3 PLT index after heating treatment for different temperatures. The intervals of $I_{\mathrm{s}(50)}$ have been defined according to Bieniawski (1975)

Both cooling systems showed a linear trend providing coefficients of determination $\left(R^{2}\right)$ of 0.94 and 0.95 for aircooled and water-cooled samples, respectively.

\subsection{Point Load Test}

PLT index decreased as temperature increased (Fig. 3). The deviations of the results were significant for samples heated to $200{ }^{\circ} \mathrm{C}$. Two of the samples exposed to $900^{\circ} \mathrm{C}$ and quickly cooled were disaggregated and broken following immersion in water, and the graph below shows the results of those that stayed whole after the cooling process (two of the five).

Similar to UCS tests, the PLT results showed low scattering — with the exception of samples exposed to $200^{\circ} \mathrm{C}$ - for both cooling methods. Beyond the target temperatures of $400{ }^{\circ} \mathrm{C}$, there is a strong decrease in the PLT index in aircooled samples.

The PLT index showed a continuous and gradual reduction of strength as temperature increased. The decreases in PLT index were 54.5 and $69.4 \%$ for slow- and quick-cooling methods, respectively, at $900{ }^{\circ} \mathrm{C}$, and so strength loss for the highest temperature (i.e. $900{ }^{\circ} \mathrm{C}$ ) was lower than that registered for UCS.

Quickly cooled samples showed lower PLT index values than those cooled slowly for most of the temperatures (Fig. 3). However, there are no differences between both cooling methods in samples exposed to 500 and $600{ }^{\circ} \mathrm{C}$. The most important difference in the results obtained for the slow-cooled samples and quick-cooled ones was observed for samples exposed to $400{ }^{\circ} \mathrm{C}(31 \%)$. Other differences between both cooling treatments are observed for samples exposed to $200,300,700$ and $900{ }^{\circ} \mathrm{C}$ whose differences are $16.7,14.6,12.2$ and $14.9 \%$, respectively. These differences 


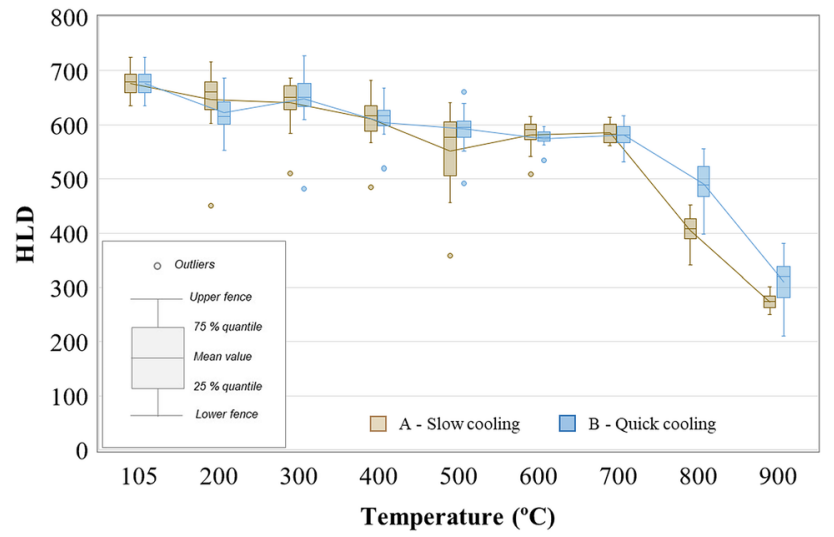

Fig. 4 Leeb's hardness index after heating treatment for different temperatures

are similar to those observed for the UCS tests. The same trend was also observed in UCS results.

Both cooling methods showed decreasing linear trends. The coefficients of determination $\left(R^{2}\right)$ were 0.81 and 0.83 for air- and water-cooled samples, respectively.

\subsection{Leeb Rebound Hardness Test}

As it can be seen in Fig. 4, HLD varies slowly and gradually up to $700^{\circ}$ (less than $15 \%$ ) and then falls sharply. Therefore, samples exposed to the highest temperatures showed a significant decrease in HLD values. These changes were similar for both cooling methods up to $700{ }^{\circ} \mathrm{C}$.

Furthermore, it is worth noting that samples exposed to $500{ }^{\circ} \mathrm{C}$ and slowly cooled, exhibited a higher dispersion than the results of the other target temperatures for both cooling methods. In addition, it can be observed that the results of LHT present more outliers than the strength tests.

Nevertheless, an important difference between the results obtained for both cooling methods on samples exposed to temperatures of $800^{\circ} \mathrm{C}$ can observed. The loss of hardness on slow-cooled samples was $13 \%$ greater than quick-cooled samples. These differences are just $5 \%$ on samples exposed to $900{ }^{\circ} \mathrm{C}$ and lower on samples exposed to temperatures up to $700{ }^{\circ} \mathrm{C}$.

Linear correlations with temperature showed similar coefficients of determination, $R^{2}$, of 0.85 and 0.86 for quick- and slow-cooled samples, respectively.

\subsection{UCS and $\mathrm{I}_{s(50)}$ Correlation}

In this study, the results of regression analyses provided $\beta$ values of 30.1 for intact samples for Eq. (1) and this represents a linear function passing through the origin. After thermal treatment of samples, conversion factors for slowly cooled and quickly cooled samples were of $\beta_{\mathrm{A}}=28.8$ and
$\beta_{\mathrm{W}}=30.7$, respectively (Fig. 5a). The coefficients of determination $\left(R^{2}\right)$ were 0.74 and 0.79 for slow- and quick-cooled treatments, respectively.

A non-random dispersion pattern is observed in the residuals plot. The residuals are greater for UCS values predicted by the model for temperatures between 500 and 900 ${ }^{\circ} \mathrm{C}$ (Fig. 5b).

\subsection{UCS and HLD Correlation}

Figure $6 a$ depicts the regression obtained in this study for both cooling methods, showing high coefficients of determination and a good correlation between UCS and HLD. Both cases showed that the expected results for the UCS of the samples subjected to slow cooling were slightly higher than for quick cooling, as experimentally observed.

The obtained coefficients of determination $\left(R^{2}\right)$ were 0.96 and 0.94 for slow- and quick-cooled treatments, respectively. A non-random dispersion pattern was observed in the residuals plot because the residuals were greater for the UCS values predicted by the model up to $700{ }^{\circ} \mathrm{C}$ (Fig. 6b).

The relationship between UCS and HLD obtained on BL samples exposed to high temperatures for both cooling methods by means of Eq. (2) are similar to those published for other limestones (Verwaal and Mulder 1993) and carbonate rocks (Gomez-Heras et al. 2020) (Table 3). As the literature shows, exponential correlations have also been studied between UCS and HLD, although the potential model adopted in this work usually provides better results.

\section{Discussion}

This work studies the variation in strength and hardness on 'Pedra de Borriol' limestone, a Cretaceous natural stone, exposed to high temperatures, by means of UCS test, PLT and LHT. Furthermore, this study explores the possibility to estimate UCS through PLT or LHT. The motivation of this work is that PLT and LHT are faster and easier than UCS test, less demanding in terms of the preparation and number of samples required, and both can be done in laboratory or in situ. In addition, on thermally affected rocks, especially those belonging historical heritages, it is very difficult to drill samples for laboratory tests. In these cases, it is common to use $\mathrm{SH}$ as an alternative to estimate strength without damaging the stone structure weakened by fire. In this paper, the use of LHT is investigated since it presents more advantages (which will be detailed later) than $\mathrm{SH}$, as the lower impact energy which makes it less harmful for testing damaged structures made of rock. Few papers have focused on this topic and it can be relevant for the evaluation of the integrity of protected heritage buildings made of this natural stone and affected by fire. 
Fig. 5 a Correlations of UCD and $I_{\mathrm{s}(50)}$ by means of linear functions, for air- and watercooled samples. b Plotted residuals

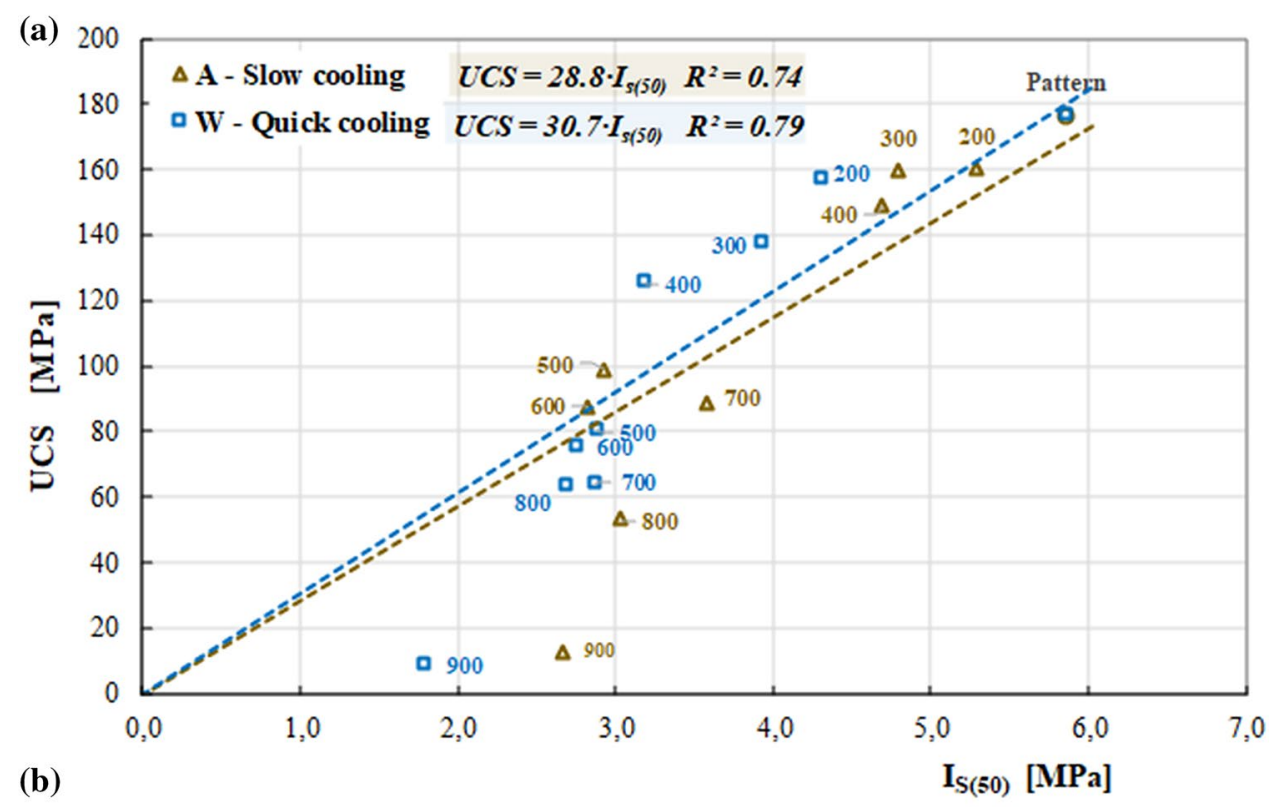

(b)

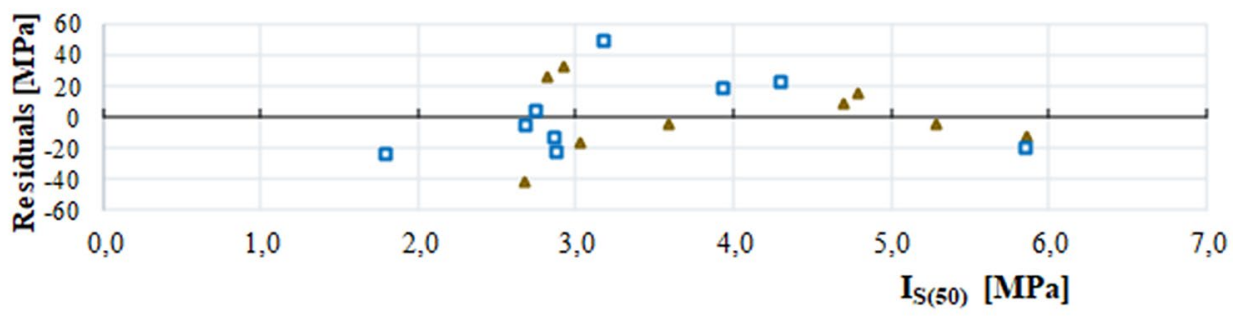

The studied limestone is mainly composed of calcite and dolomite with traces of quartz, illite, goethite and hematite (Ovejero et al. 2005). It has a low porosity ( $2.4 \%$ total porosity) and its dry densities are 2.662 and $2.669 \mathrm{~kg} \mathrm{~m}^{-3}$ for cylindrical and prismatic samples, respectively. The means the UCS, point load test index, and Leeb rebound hardness index are $176.8 \mathrm{MPa}, 5.86 \mathrm{MPa}$ and 677 , respectively.

The current study confirms that strength and hardness exhibited a general decrease even from the lowest temperature values of $105^{\circ} \mathrm{C}$, in agreement with the results reported by different authors on limestones (Ferrero and Marini 2001; Mao et al. 2009; Ozguven and Ozcelik 2014). As shown in Fig. 7, according to the evolution of the UCS with temperature, different types of behaviours can be recognised. Some types of limestones show an initial increase in UCS followed by a drop in strength up to values close to the initial strength at temperatures of $600^{\circ} \mathrm{C}$ (Ferrero and Marini 2001). However, most of the compiled works focused on the behaviour of heated limestones show a gradual decrease in strength as the target temperature increases (Mao et al. 2009; Ozguven and Ozcelik 2014). This is similar to that observed for Pedra de Borriol.

The Borriol limestone specimens exposed to different temperature up to $900^{\circ} \mathrm{C}$ showed an important UCS reduction, higher than $90 \%$. Similarly, Ozguven and Ozcelik
(2014) observed a UCS loss close to $90 \%$ at $1000{ }^{\circ} \mathrm{C}$, on samples cooled to room temperature inside the oven. Mao et al. (2009) also reported a loss of strength close to $80 \%$ at $800{ }^{\circ} \mathrm{C}$ on limestone samples. Some publications also studied the effect of slow- and quick-cooling methods on mechanical properties of rocks, although none studied limestones. Brotóns et al. (2013) reported that uniaxial compressive strength for San Julian's calcarenite is very sensitive to the cooling method, with a strength reduction of up to $35 \%$ for air-cooled samples, and more than $50 \%$ for watercooled samples at $600{ }^{\circ} \mathrm{C}$. In comparison, BL shows a loss of strength of $50.3 \%$ for air-cooled samples and $57.2 \%$ for water-cooled samples at the same temperature. Kumari et al. (2017) stated that the influence of rapid cooling is much greater than that of slow cooling on granite due to sudden thermal shock.

In the current study, differences between the two cooling methods are almost negligible, since the strength decreases by up to 92.7 and $95.0 \%$ at $900{ }^{\circ} \mathrm{C}$ for slow- and quickcooling methods, respectively. In addition, both cooling methods exhibited near parallel trends and data showed a good linear correlation for both slow-cooled $\left(R^{2}=0.94\right)$ and quick-cooled samples $\left(R^{2}=0.95\right)$.

The highest data dispersion corresponds to air-cooled samples exposed at $200{ }^{\circ} \mathrm{C}$ and water-cooled samples 
Fig. 6 a Correlations of UCD and HLD by means of potential functions, for air- and watercooled samples. b Plotted residuals
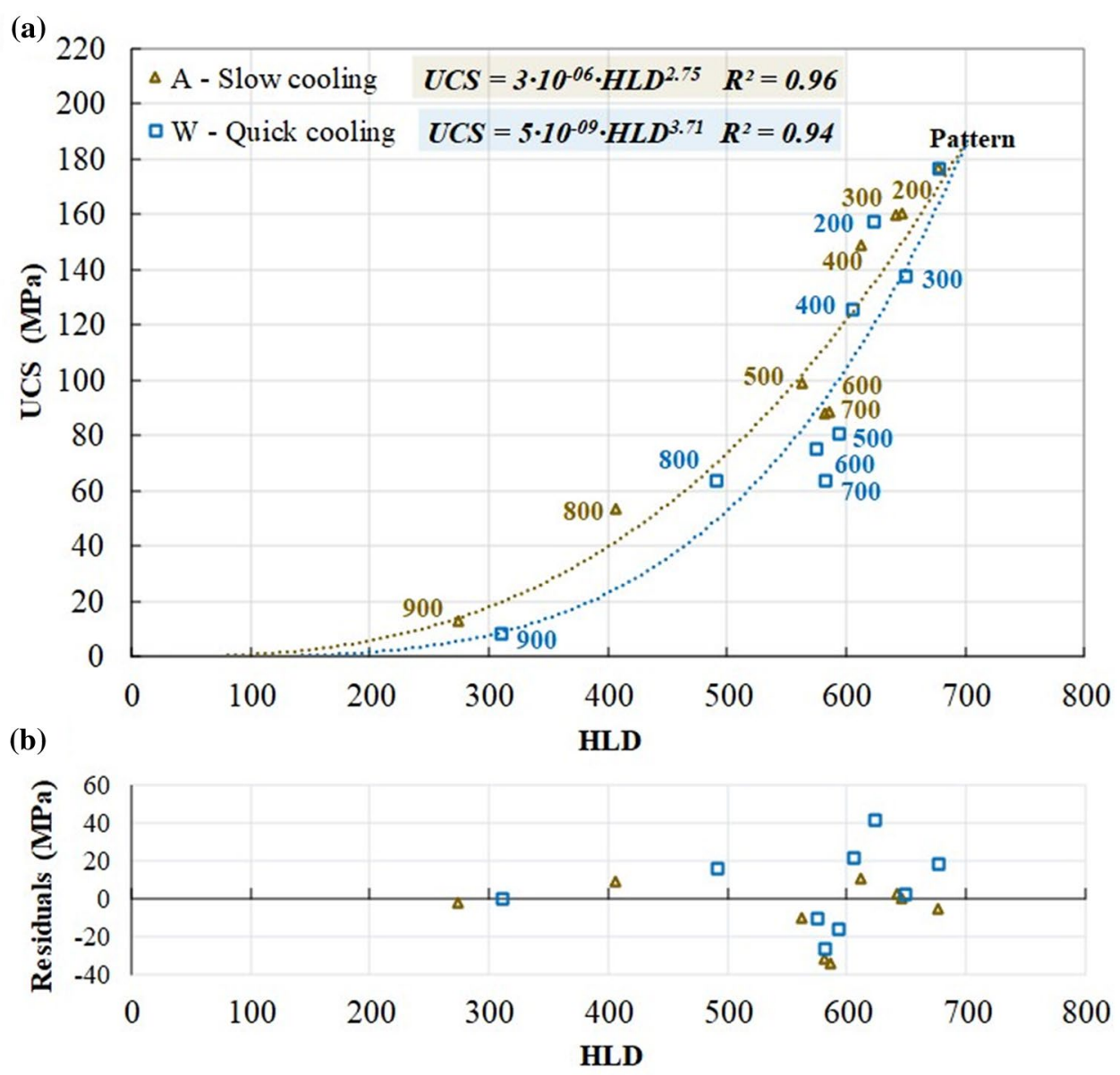

Table 3 Comparative characteristics of tests used to determine rock strength

\begin{tabular}{|c|c|c|c|c|c|c|}
\hline Test & Field estimation method & UCS & $\mathrm{SH}^{\mathrm{b}}$ & PLT & $\mathrm{NPT}^{\mathrm{b}}$ & LHT \\
\hline $\begin{array}{l}\text { Range of application for UCS determi- } \\
\text { nation (MPa) }\end{array}$ & Unlimited & Unlimited & $10-400$ & $1-250$ & $<20$ & $5-250^{\mathrm{a}}$ \\
\hline Determination of UCS & Indirect & Direct & Indirect & Indirect & Indirect & Indirect \\
\hline Application & FLD & LAB & FLD/LAB & FLD/LAB & FLD/LAB & FLD/LAB \\
\hline Specimen preparation requirements & No & $\mathrm{Yes}^{\mathrm{c}}$ & No & No & No & No \\
\hline Destructive test type & No & Yes & No & Yes & No & No \\
\hline Relative cost & Very low & High & Low & Low & Low & Low \\
\hline Sensitivity & Extremely low & Medium & Low & Low & High & High \\
\hline Test duration $^{\mathrm{d}}$ & Very short & Long & Very short ${ }^{\mathrm{e}}$ & Short ${ }^{\mathrm{e}}$ & Very short ${ }^{\mathrm{e}}$ & Very short $\mathrm{t}^{\mathrm{e}}$ \\
\hline Time to results calculation & Very short & Short & Very short & Long & Short & Very short \\
\hline
\end{tabular}

$F L D$ field, $L A B$ laboratory

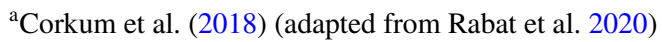

${ }^{\mathrm{b}}$ There are no known publications on rocks exposed to high temperatures subjected to this test

${ }^{\mathrm{c}}$ Some difficulties in preparing soft rock specimens

${ }^{\mathrm{d}}$ Including time required for specimen preparation

'This time can be 'long' when testing using regular (cylindrical) specimens. 


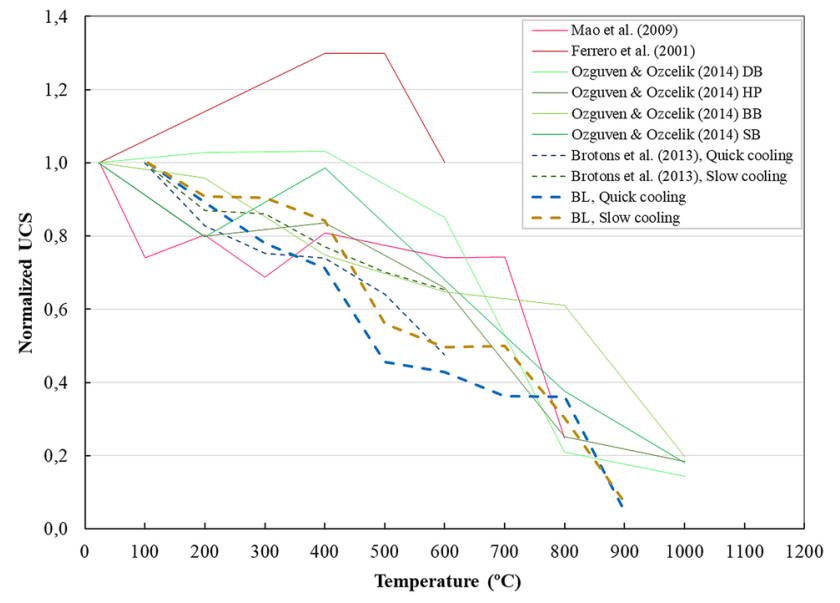

Fig. 7 Evolution of the normalised values of UCS against temperature on limestones, observed by different authors and those obtained in the present study

exposed at $300{ }^{\circ} \mathrm{C}$. Up to $300{ }^{\circ} \mathrm{C}$, no relevant mineralogical changes are considered, hence, the main effect would be thermal microcracking induced by a differential thermal expansion of different rock compounds. This phenomenon occurs in monomineral rocks that exhibit anisotropic expansions due to the random orientation of minerals. The main mineral in BL is calcite (75-85\%) and differential thermal dilatations are expected to be due to its anisotropic expansion (expansion along the c-axis and contraction perpendicularly to this axis) from 200 to $300^{\circ} \mathrm{C}$ (Lion et al. 2005; Yang et al. 2019). These processes may be the reason of the higher deviation of most of the mechanical properties observed at this temperature range. The cracking due to the anisotropy thermal expansion of the calcite crystals produces a complete separation at grain boundaries. It is important in aggregates or rocks with low porosity as BL is (Rosengren \& Jaenger, 1968).

Under $200{ }^{\circ} \mathrm{C}$, limonite is dehydrated to goethite (Eq. 4) at low temperatures (Pomiès et al. 1999). Between 200 and $300{ }^{\circ} \mathrm{C}$, the goethite is dehydroxylated (Eq. 5) and becomes hematite. This transformation finishes at around $400{ }^{\circ} \mathrm{C}$ and is associated with a notable colour change from yellow (goethite phase) to reddish (hematite phase) (González-Gómez et al. 2015; Pomiès et al. 1999) and is also observed in BL samples:

$$
\begin{aligned}
& \mathrm{FeO}(\mathrm{OH}) \times n \mathrm{H}_{2} \mathrm{O} \rightarrow \mathrm{FeO}(\mathrm{OH}) \\
& \quad+\mathrm{H}_{2} \mathrm{O}(\text { Limonite } \rightarrow \text { Goethite + Water })
\end{aligned}
$$

$2 \mathrm{FeO}(\mathrm{OH}) \rightarrow \mathrm{Fe}_{2} \mathrm{O}_{3}+\mathrm{H}_{2} \mathrm{O}$ (Goethite $\rightarrow$ Hematite + Water)

BL uniaxial compression strength sharply decreases between 400 and $500{ }^{\circ} \mathrm{C}$ for both cooling methods, $28 \%$ for slow cooling and $25 \%$ for quick cooling. This sudden change is mainly associated with the dehydrogenation of constitution water in the vaporisation process (Zhang et al. 2016). In addition, in this range of temperature, a thermal stress concentration between minerals with different thermal expansion coefficients increases microcracking (Liu and Xu 2014; Villarraga et al. 2018; Yang et al. 2019). Furthermore, some research findings describe the slow decomposition of dolomite (Eq. 6) at temperatures close to $500{ }^{\circ} \mathrm{C}$ and an increase in the rate of decomposition (Zhang and Lv 2020):

$\mathrm{CaMg}\left(\mathrm{CO}_{3}\right)_{2} \rightarrow \mathrm{Ca}\left(\mathrm{CO}_{3}\right)+\mathrm{MgO}+\mathrm{CO}_{2}$.

Therefore, the range of temperatures between 400 and $500{ }^{\circ} \mathrm{C}$ configures a clear threshold for thermal cracking (Meng et al. 2020; Martinez-Ibañez et al. 2020a) of BL.

Major mineral transformations are only visible beyond $600{ }^{\circ} \mathrm{C}$. The calcination of calcium carbonate begins at $600{ }^{\circ} \mathrm{C}$ and proceeds rapidly beyond $800{ }^{\circ} \mathrm{C}$. After $700^{\circ} \mathrm{C}$, the calcium carbonate become lime and carbon dioxide due to calcination (Eq. 7), causing a rapid degradation clearly observed on samples heated at higher temperatures:

$\mathrm{Ca}\left(\mathrm{CO}_{3}\right)+$ Temperature $\rightarrow \mathrm{CaO}+\mathrm{CO}_{2}$.

Leaving the samples at room temperature induces the appearance of a new mineral phase, portlandite, $\mathrm{Ca}(\mathrm{OH})_{2}$, from the reaction of the lime generated from the calcination of the calcite with the air humidity or by the immersion of the samples in water (Eq. 8). This portlandite reaction has been previously reported for limestones (Chakrabarti et al. 1996). The formation of portlandite is associated with a volume increase and leads to the disintegration of heated samples. This kind of sample disintegration (portlandite reaction) was not observed when dolomite was the main carbonate, although the carbonate phase disappeared above $750{ }^{\circ} \mathrm{C}$ (Becattini et al. 2017; Török and Hajpál 2005). Calcite and magnesite can be totally disintegrated at higher temperatures $\left(900^{\circ} \mathrm{C}\right)$ with test specimens collapsing due to portlandite reactions (Sirdesai et al. 2017; Török and Hajpál 2005):

$\mathrm{CaO}+\mathrm{HO}_{2} \rightarrow \mathrm{Ca}(\mathrm{OH})_{2}$.

As previously shown in Fig. 3, samples exposed at 800 ${ }^{\circ} \mathrm{C}$ and quickly cooled show greater strength values than slowly cooled samples. A possible explanation is the rapid formation of portlandite according to Eq. (8) due to the immersion in tap water and the subsequent hydraulic setting that increases rock strength. This strength increase is not recorded for samples quickly cooled after being exposed to $900{ }^{\circ} \mathrm{C}$ because the lime layer is disaggregated in contact 
with water and this produces a significant reduction in mass and volume and the consequent loss of strength.

Other textural and mineralogical changes during the heating tests are related with quartz content. The changes are mainly observed at higher temperatures in the form of $\alpha-\beta$ quartz transition at $573{ }^{\circ} \mathrm{C}$. The consequence is a volumetric increase that generates thermal expansion cracks, and an increase in porosity or decrease in strength can be observed (González-Gómez et al. 2015; Huang et al. 2017; Wong et al. 2020). Clay minerals also show important changes in mineral composition and physical properties at lower temperatures and their structures disintegrate between 450 and $750{ }^{\circ} \mathrm{C}$. The effect of temperature on the traces of quartz and clays found in BL rocks (Ovejero et al. 2005) may be the reason for the small changes observed between 500 and $700{ }^{\circ} \mathrm{C}$ (Figs. 2 and 3).

Mechanical changes associated with thermally treated rock samples are mostly linked to the chemical changes described above (Vagnon et al. 2019, 2021). The average length of microcracks in granites slightly increases with temperature up to $600{ }^{\circ} \mathrm{C}$, but the number of microcracks per unit area remains approximately constant and UCS results show slight differences in this temperature range (Griffiths et al. 2017).

According to Griffiths et al. (2017), between 550 and $600{ }^{\circ} \mathrm{C}$, the density of the number of microcracks increases sharply and the average length decreases, which is attributed to the alpha-beta transition of quartz at around $573{ }^{\circ} \mathrm{C}$. This phenomenon is accompanied by a marked volume increase and intergranular thermal cracking, and consequently strength shows a notable drop. Despite the density of microcracks increases with temperature up to $600{ }^{\circ} \mathrm{C}$ for some type of rocks, most authors reported that it remains constant for higher temperatures. Griffiths et al. (2017) attributed these changes to cracks growing to a maximum length dependent on the length scale of the microstructure (i.e. grain size). These authors also observed a remarkable decrease in strength for temperatures greater than $600{ }^{\circ} \mathrm{C}$ that was attributed to more open microcracks, rather than to more developed fissures, what is consistent with the fact that microcrack density remaining constant in this range of temperatures.

References are scarce for the study of the variation of strength with temperature using the PLT test. Idris (2018) reported the relationship between PLT and high temperature on two carbonate rocks: limestone and marble. $I_{\mathrm{s}(50)}$ index shows a slightly irregular fit although an almost linear decrease can be observed with the increase of the target temperature for both limestones: BL and the limestone analysed by Idris (Fig. 8). The BL sample values of $I_{\mathrm{s}(50)}$ are higher than those observed for the rock tested by this author (Idris 2018) because the intact rock values are also higher. The determination coefficients were better for BL (i.e. $R^{2}=0.81$

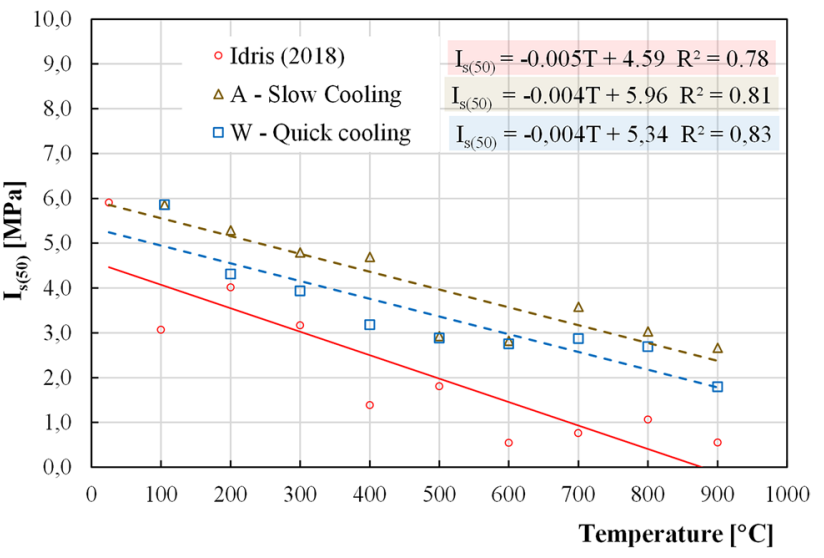

Fig. 8 Variation of $I_{\mathrm{s}(50)}$ vs temperature. Comparative with previous research

and $R^{2}=0.83$ for slow- and quick-cooled samples, respectively) than for the rocks tested by Idris $\left(R^{2}=0.78\right)$.

The calculated trend showed an irregular behaviour for limestone and strength decreased up to $86 \%$ from 200 to $900{ }^{\circ} \mathrm{C}$. It is a higher drop than that observed for the current study since at the same temperature the BL samples lost up to 54.5 and $69.4 \%$ for slow and quick cooling, respectively (Fig. 9). The most significant drops in strength obtained by the PLT are observed between 400 and $500{ }^{\circ} \mathrm{C}$ for air-cooled samples (30\%) and between 300 and $400{ }^{\circ} \mathrm{C}$ for water-cooled samples (18\%). These major changes match the temperature range for which the main mineralogical changes described above occur according to the composition of BL.

BL strength does not appear to be sensitive to the $\alpha-\beta$ quartz transition since neither the results of UCS nor those of the PLT index show significant changes between temperatures of 500 and $600{ }^{\circ} \mathrm{C}$ (Fig. 9), which was predictable considering that quartz is a minority mineral in the BL.

After studying the variation of strength with heat treatment, the aim was to analyse the changes produced by high temperatures on hardness using the HLD index. The mean value of HLD obtained for intact Borriol limestone (i.e. $677 \pm 23$ ) was similar to those obtained in previous investigations performed on limestone rocks (Gomez-Heras et al. 2020; Verwaal and Mulder 1993). However, there are no data published about HLD values on rocks exposed to high temperatures. The HLD results on BL samples exposed at different target temperatures in the current study showed similar drops to the PLT index for the highest temperatures. The final decrease was $59.5 \%$ for slow-cooled samples and $54.2 \%$ for those quick cooled (Fig. 9).

However, for temperatures lower than $700{ }^{\circ} \mathrm{C}$ the HLD decreased slowly (less than 15\%), and above that temperature the value decreased quickly (up to 59\% for air-cooled samples) (Fig. 4). None of the mineralogical changes and microcracking processes described in the previous literature due 
(a)

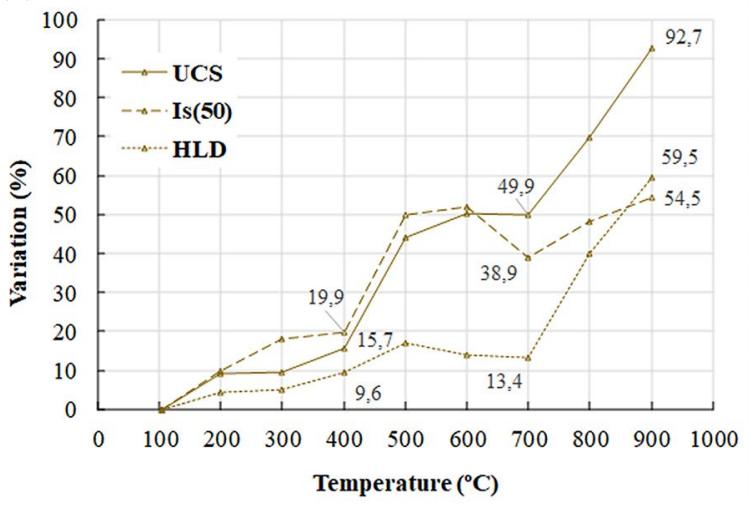

(b)

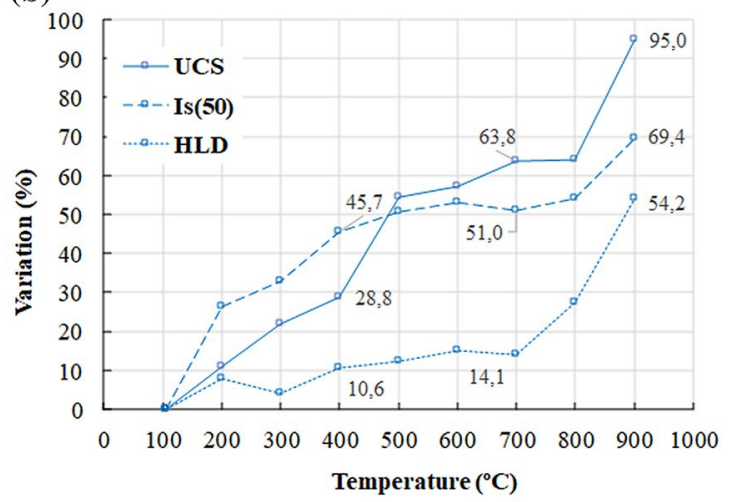

Fig. 9 Variation of UCS, $I_{\mathrm{s}(50)}$ and HLD for different target temperature for a slow-cooling; and b quick-cooling samples
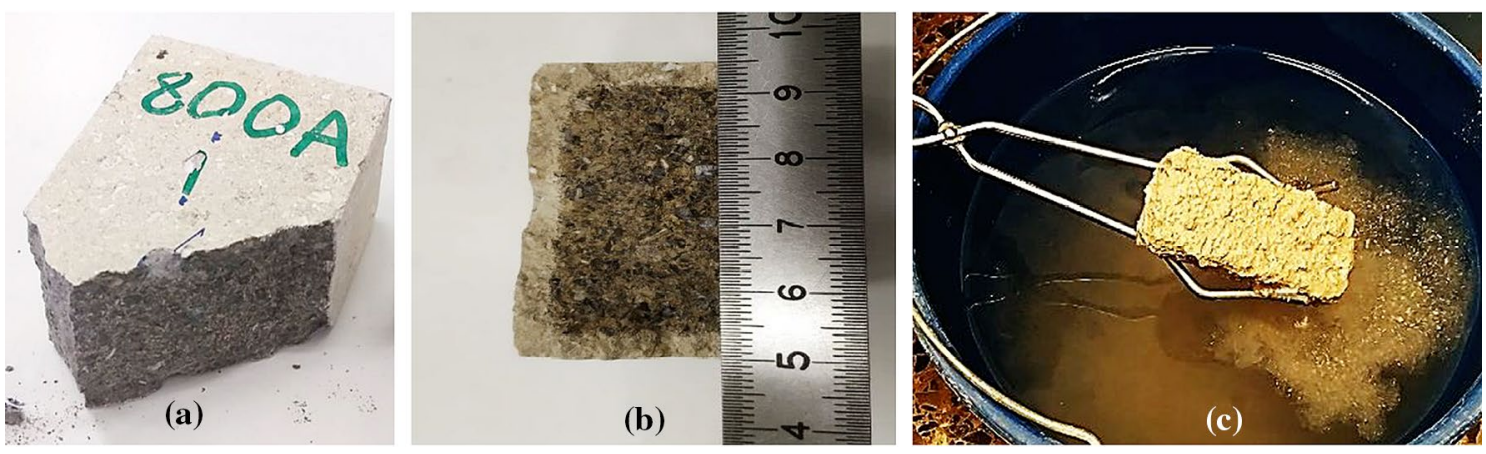

Fig. 10 Lime layer of samples a 800A (slow cooled); b 900A (slow cooled) and c degradation after immersion in water for $900 \mathrm{~W}$ (quick cooled)

to temperature exposition up to $700^{\circ} \mathrm{C}$ seems to influence BL surface hardness. For that reason, $700^{\circ} \mathrm{C}$ is a threshold temperature for hardness of Borriol limestone. Beyond this temperature, the calcination of calcite and dolomite is the main process that produces changes in this rock (Eqs. 7 and $8)$ and creates a superficial lime $(\mathrm{CaO})$ layer. This layer has a thickness of 1-4 $\mathrm{mm}$ in the BL and it increases with target temperature (Fig. 10a, b). The literature reports that this layer rarely exceeds $20 \mathrm{~mm}$ (Chakrabarti et al. 1996).

The hardness decline for slow-cooling samples was higher than for quick-cooled specimens at $900{ }^{\circ} \mathrm{C}$. By contrast, UCS and PLT tests show higher reductions in quickcooled samples, probably because water disaggregates the thin layer of lime when samples were immersed (Fig. 10c).

Strength (i.e. UCS and PLT) and hardness (i.e. LHT) tests showed different trends (Fig. 9). Temperature changes produce microcracks in the rock matrix that are clearly manifested in mechanical properties (i.e. a reduction in the UCS and PLT index) and that agrees the results of previous published works (Corkum et al. 2018; Ozguven and Ozcelik 2014; Yang et al. 2019). However, this effect is not observed on hardness results. Then, chemical changes modify certain minerals, both superficially and internally, and LHT reveals such changes at above $700{ }^{\circ} \mathrm{C}$. In fact, UCS, PLT and LHT exhibit a similar trend from $700^{\circ} \mathrm{C}$.

In summary, the UCS and PLT tests measure general structural changes of rock matrix, while LHT only measures surface changes. The formers manifest important changes caused by mineralogical changes and microcracks induced by thermal treatment from initial temperatures. In contrast, the latter only exhibits significant changes from a temperature of $700{ }^{\circ} \mathrm{C}$, from which the composition of the minerals considerably changes, mainly on the surface of the specimens.

Once the evolution of each parameter with temperature was analysed, the possibility of obtaining UCS based on PLT and LHT was studied. It is common to use PLT for the indirect estimation of UCS. Thus, many researchers have proposed several correlations based on tests carried out on different rock types, as shown in Fig. 11a. However, the estimation of UCS using these correlations for different rock types could provide a large variability of results. Therefore, it is highly recommended to develop UCS $-I_{\mathrm{s}(50)}$ 

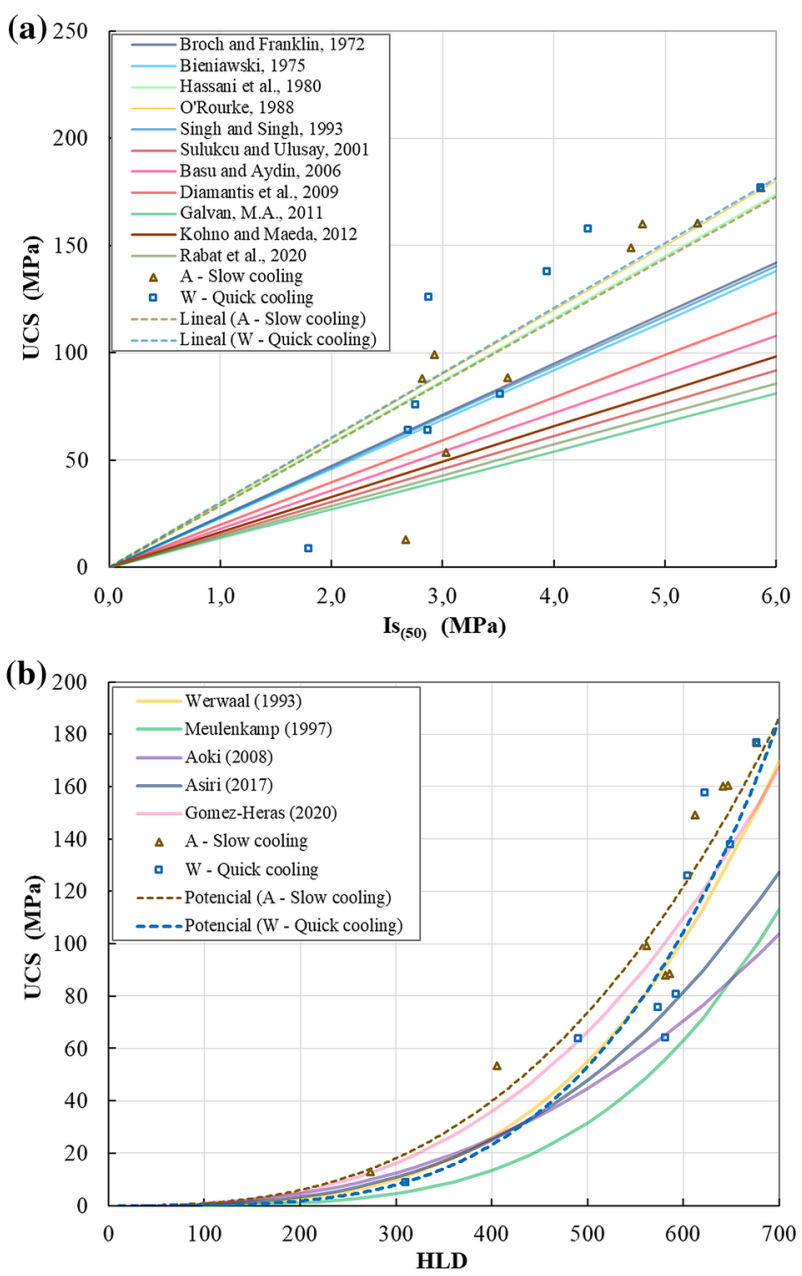

Fig. 11 Correlations between UCS and $\mathbf{a} I_{\mathrm{s}(50)}$ and b HLD. A comparison with previous research

correlations for each specific rock type and local lithology (Elhakim 2015).

The $\beta$ values obtained for BL were greater than other known relationships and close to the results obtained by Hassani et al. (Hassani, Scoble, \& Whittaker, 1980) and O'Rourke (O'Rourke 1989) for intact sedimentary rocks. The coefficients of determination obtained in this work $\left(R^{2}\right.$ between 0.73 and 0.79 ) were not among the best-fitting correlations in existing research, although they provide a first approximation for the determination of UCS from PLT for BL. Although there are no significant differences depending on the cooling method, the $\beta$ value was smaller for slowcooled samples than for quick-cooled samples. Furthermore, predicted values were worse for higher temperatures (Fig. 11a).

Figure $11 \mathrm{~b}$ plots HLD-UCS correlations proposed by different authors on intact rocks as well as those obtained for BL exposed to high temperatures. Current research shows a fairly good correlation between HLD and UCS using power functions according to existing literature. The coefficients of determination were higher than those reported in previous studies (i.e. $\mathrm{R}^{2} 0.96$ and 0.94 for slow and quick cooling, respectively) and similar to those reported by GomezHeras et al. (2020) for carbonated rocks, and Verwaal and Mulder (1993) on various limestones. Power functions enable obtaining UCS as a function of HLD on BL samples exposed to high temperatures; the values are higher than other correlations obtained for intact rocks (Fig. 11b). It appears that exposure to high temperatures does not exert a major effect on the type of relation between UCS and HLD, although there is a slight difference between both cooling methods, since slow-cooling samples showed higher values than quick-cooling methods.

Although the use of $\mathrm{R}^{2}$ might not be an efficient way to evaluate the performance of the fitting models, most of the previous research on UCS-PLT index or UCS-HLD correlations have established the coefficient of determination (see Tables 1 and 2) as reference value to determine the goodness of the regression analysis [52]. Other investigations in the field of rock mechanics have gone further adding other criteria as the $t$-test or the F-test to validate of the models (Aydin et al. 2013; Karakurt et al. 2012). In this study, the Symmetric Mean Absolute Percentage Error (SMAPE) and the Mean Absolute Percentage Error (MAPE) have been calculated for evaluating the forecasting performance. On the one hand, the proposed UCS-PLT correlations provide SMAPEs of 14.7 and $15.5 \%$ for slow and quick cooling, respectively. Similarly, the UCS-HLD correlations provide SMAPEs of 13.3 and $17.3 \%$ for slow and quick cooling, respectively. On the other hand, the proposed UCS-PLT correlations provide MAPE values of 22.0 and $24.1 \%$ for slowand quick-cooling samples, respectively, and 12.4 and $18.0 \%$ for slow and quick cooling, respectively, for UCS-HLD correlations. These results can be considered as "good forecasting" (Lewis 1982).

Finally, Table 3 shows a comparative analysis of the different tests available to obtain UCS has been performed considering previous experiences and the results of this study.

According to this analysis, it can be observed that the most important advantages of LHT in comparison with other methods to predict UCS are: (a) it is non-destructive and so uniaxial compressive strength is indirectly estimated; (b) it does not require special specimen preparations nor heavy expensive equipment; (c) it can be used in the field and in the laboratory; and (d) testing and results calculation can be completed quickly. These characteristics make LHT especially suitable for the indirect evaluation of mechanical properties of cultural and protected heritage made of natural stone.

Future work could focus on better checking the chemical changes described in this document including other type of tests as X-ray diffraction. To verify the microtexture 
changes, it would be convenient to introduce images of Scanning Electron Microscope and Mercury Intrusion Porosimetry results. These tests would allow observing the progression of microcracks and pores as temperature increase. In addition, it would be very interesting to apply the image analysis procedure proposed by Griffiths et al. (2017) to quantify the thermal damage on BL in terms of microcrack density progress and its relationship with strength and hardness variation as temperature increase. Furthermore, since P-wave velocity seems to be a suitable technique, it would be interesting to apply it for analysing the degree of damage, the overall porosity, and the orientation and the size of microcracks.

\section{Conclusions}

This study analyses the effect of high temperatures on the strength and hardness of a cretaceous limestone, commonly used in the construction of historic monuments in the east of Spain. UCS and PLT tests were used to evaluate rock strength. LHT type 'D' was also used to evaluate surface hardness. Furthermore, this work explores correlations to predict UCS from the PLT index and HLD. The following are the main conclusions:

1. The effect of exposure to high temperatures on BL strength has been studied by means of UCS and PLT. The results from both tests are adversely affected by the heating process. The BL specimens exposed to different temperatures up to $900{ }^{\circ} \mathrm{C}$ show a significant UCS reduction, up to 92.7 and $95.0 \%$ for slow and quick cooling, respectively. The rate of decrease is similar for both cooling methods, although quick-cooling results are always slightly lower than those obtained for slow cooling. Both cooling systems show a good linear correlation with temperature. In the same way, the results show a continuous reduction in PLT index up to 54.5 and $69.4 \%$ for slow and quick cooling, respectively, as temperature increases up to $900{ }^{\circ} \mathrm{C}$. The results obtained in quick-cooled samples are always lower than slow-cooled samples. It is possible to observe important differences depending on the cooling methods at 400, 700 and $900{ }^{\circ} \mathrm{C}$. This enables establishing the evolution of this property for each recorded temperature value since a good correlation of $\mathrm{I}_{\mathrm{s} 50}$ with temperature has been found.

2. The effect of exposure to high temperatures on BL hardness was studied by LHT using an Equotip type 'D'. HLD losses of up to $59.5 \%$ on slow-cooling samples and $54.2 \%$ on quick-cooling samples for the highest temperature were recorded. Until $700{ }^{\circ} \mathrm{C}$ the hardness decreases slowly up to $15 \%$, and above this temperature the value quickly decreases. The reason may be the appearance of a thin and weak lime layer on the surface of those samples exposed to 800 and $900{ }^{\circ} \mathrm{C}$. The decrease in hardness at $900{ }^{\circ} \mathrm{C}$ on slow-cooled samples is higher than quick-cooled samples unlike what is observed in the results of strength tests. This fact may be due to the desegregation of this lime layer on samples cooled by immersion. There are no important differences determined by the cooling method in the evolution of BL hardness.

3. Two threshold temperatures have been identified at $400{ }^{\circ} \mathrm{C}$ for strength and $700{ }^{\circ} \mathrm{C}$ for hardness. UCS presents a sharp decrease between 400 and $500{ }^{\circ} \mathrm{C}$ for both cooling methods of $28 \%$ for slow cooling and $25 \%$ for quick cooling. In the same way, PLT shows a significant drop in the range of $400-500{ }^{\circ} \mathrm{C}$, or nearly $30 \%$ on slow-cooled samples. In this range of temperatures, change is mainly associated with the dehydrogenation of constitution water in the vaporisation process. In addition, thermal stress concentration of minerals with different thermal expansion coefficients increases microcracking. None of the changes due to exposure up to $700{ }^{\circ} \mathrm{C}$ seem to influence BL hardness. Beyond this temperature, the calcination of calcite and dolomite produces changes in limestones that create a superficial and weak lime layer. This process could explain the differences in hardness before and beyond this temperature.

4. This study provides new correlations to estimate UCS by means of $I_{\mathrm{s}(50)}$ and HLD on BL exposed to high temperatures. The linear regression between UCS and $I_{\mathrm{s}(50)}$ provides acceptable determination coefficients of 0.74 and 0.73 for slow- and quick-cooling methods, respectively. The correlation between UCS and HLD shows the best fit with power functions. It reveals significant relationships between the strength and hardness properties of this rock. The determination coefficients are 0.96 and 0.94 for slow- and quickcooling methods, respectively. On BL exposed to high temperatures, the relationships obtained in both cases (i.e. UCS $-I_{\mathrm{s}(50)}$ and UCS-HLD) are very similar to those previously obtained by the other authors on intact rocks.

5. HLD is insensitive to the edge effect or sample size, and rebound energy is low enough to ensure the integrity of heritage and historic buildings exposed to fire. Therefore, the correlations explored in this research indicate that Leeb rebound hardness tests can be used to indirectly estimate UCS on rocks exposed to high temperatures and provide acceptable predictions.

In summary, this research considerably improves knowledge of the behaviour of the Pedra de Borriol rock when exposed to high temperatures and cooled by different methods. In addition, the obtained correlations enable the evaluation of geomechanical parameters of elements of cultural heritage made of Pedra de Borriol affected by fires to estimate their integrity level.

Future work will focus on better verifying the chemical changes described in this document, adding other types of tests, as well as procedures to quantify mechanical damage in BL with increasing exposure temperature. 
Acknowledgements The authors acknowledge the support by Canteras Bernad $S L$ which has generously provided samples, and Department of Geotechnical and Geological Engineering of Universitat Politècnica de València and Department of Civil Engineering of Universidad de Alicante, for its continuous support.

Author contributions MEG: conceptualisation, methodology, laboratory tests, writing - original draft preparation, reviewing and editing. FBP: laboratory tests. VM-I: conceptualisation, methodology and reviewing manuscript. JBS: conceptualisation, methodology and reviewing manuscript. CH-S: conceptualisation, methodology, laboratory tests, supervision and reviewing manuscript. RT: conceptualisation, methodology, supervision and reviewing manuscript. All the authors have read and agreed to the published version of the manuscript.

Funding Open Access funding provided thanks to the CRUE-CSIC agreement with Springer Nature.

\section{Declarations}

Competing interest The authors declare that they have no known competing financial interests or personal relationships that could have appeared to influence the work reported in this paper.

Open Access This article is licensed under a Creative Commons Attribution 4.0 International License, which permits use, sharing, adaptation, distribution and reproduction in any medium or format, as long as you give appropriate credit to the original author(s) and the source, provide a link to the Creative Commons licence, and indicate if changes were made. The images or other third party material in this article are included in the article's Creative Commons licence, unless indicated otherwise in a credit line to the material. If material is not included in the article's Creative Commons licence and your intended use is not permitted by statutory regulation or exceeds the permitted use, you will need to obtain permission directly from the copyright holder. To view a copy of this licence, visit http://creativecommons.org/licenses/by/4.0/.

\section{References}

Aoki H, Matsukura Y (2008) Estimating the unconfined compressive strength of intact rocks from Equotip hardness. Bull Eng Geol Environ 67(1):23-29. https://doi.org/10.1007/s10064-007-0116-z

Armaghani DJ, Tonnizam Mohamad E, Momeni E, Monjezi M, Sundaram Narayanasamy M (2016) Prediction of the strength and elasticity modulus of granite through an expert artificial neural network. Arab J Geosci 9(1):48. https://doi.org/10.1007/ s12517-015-2057-3

Aydin A (2009) ISRM Suggested method for determination of the Schmidt hammer rebound hardness: revised version. Int J Rock Mech Min Sci 46(3):627-634. https://doi.org/10.1016/j.ijrmms. 2008.01.020

Aydin G, Karakurt I, Aydiner K (2013) Prediction of the cut depth of granitic rocks machined by abrasive waterjet (AWJ). Rock Mech Rock Eng 46(5):1223-1235. https://doi.org/10.1007/ s00603-012-0307-1

Barton N (1979) Suggested methods for the quantitative description of discontinuities in rock masses. Int J Rock Mech Min Sci Geomech Abstr 16(2):22. https://doi.org/10.1016/0148-9062(79)91476-1
Barton N, Choubey V (1977) The shear strength of rock joints in theory and practice. Rock Mech 10(1):1-54. https://doi.org/10. 1007/BF01261801

Basu A, Aydin A (2006) Predicting uniaxial compressive strength by point load test: significance of cone penetration. Rock Mech Rock Eng 39:483-490. https://doi.org/10.1007/s00603-006-0082-y

Becattini V, Motmans T, Zappone A, Madonna C, Haselbacher A, Steinfeld A (2017) Experimental investigation of the thermal and mechanical stability of rocks for high-temperature thermal-energy storage. Appl Energy 203:373-389. https://doi.org/10.1016/j. apenergy.2017.06.025

Bieniawski ZT (1974) Estimating the strength of rock materials. J S Afr Inst Min Metall 74:312-320

Bieniawski ZT (1975) The point-load test in geotechnical practice. Eng Geol 9(1):1-11

Bieniawski ZT, Bernede MJ (1979) ISMR Suggested methods for determining the uniaxial compressive strength and deformability of rock materials: part 1. Int J Rock Mech Min Sci Geomech 16(2):138-140. https://doi.org/10.1016/0148-9062(79)91451-7

Broch E, Franklin JA (1972) The point-load strength test. Int J Rock Mech Min Sci Geomech Abstr 9(6):669-676

Brotóns V, Tomás R, Ivorra S, Alarcón JC (2013) Temperature influence on the physical and mechanical properties of a porous rock: San Julian's calcarenite. Eng Geol 167:117-127. https://doi.org/ 10.1016/j.enggeo.2013.10.012

Brotóns V, Tomás R, Ivorra S (2014) A calcarenite exposed to true fire conditions: A methodological proposal. In: Rock Engineering and rock mechanics: structures in and on rock masses-Proceedings of EUROCK 2014, ISRM European Regional Symposium, (May)

Chakrabarti B, Yates T, Lewry A (1996) Effect of fire damage on natural stonework in buildings. Constr Build Mater 10(7):539-544. https://doi.org/10.1016/0950-0618(95)00076-3

Chen YL, Ni J, Shao W, Azzam R (2012) Experimental study on the influence of temperature on the mechanical properties of granite under uni-axial compression and fatigue loading. Int J Rock Mech Min Sci 56:62-66. https://doi.org/10.1016/j.ijrmms.2012.07.026

Corkum AG, Asiri Y, El Naggar H, Kinakin D (2018) The leeb hardness test for rock: an updated methodology and UCS correlation. Rock Mech Rock Eng 51(3):665-675. https://doi.org/10.1007/ s00603-017-1372-2

David C, Menéndez B, Darot M (1999) Influence of stress-induced and thermal cracking on physical properties and microstructure of $\mathrm{La}$ Peyratte granite. Int J Rock Mech Min Sci 36:433-448

Deere DU, Miller RP (1965) Engineering classification and index properties for intact rock. Air Force weapons laboratory, Kirtland Air Base. New Mexico, Technical Report AFWL-TR-65-115.

Diamantis K, Gartzos E, Migiros G (2009) Study on uniaxial compressive strength, point load strength index, dynamic and physical properties of serpentinites from Central Greece: Test results and empirical relations. Eng Geol 108(3-4):199-207. https://doi.org/ 10.1016/j.enggeo.2009.07.002

Elhakim AF (2015) The use of point load test for Dubai weak calcareous sandstones. J Rock Mech Geotech Eng 7(4):452-457. https:// doi.org/10.1016/j.jrmge.2015.06.003

Ferrero AM, Marini P (2001) Experimental studies on the mechanical behaviour of two thermal cracked marbles. Rock Mech Rock Eng 34(1):57-66. https://doi.org/10.1007/s006030170026

Franklin J (1979) ISRM Suggested methods for determining water content, porosity, density absorption and related properties and swelling and slake-durability index properties. Int J Rock Mech Min Sci 16(2):143-151

Galvan M, Preciado J, Seron JB (2014) Correlation between the point load index, Is (50), and the resistance to unconfined compression in limestone from the comunidad valenciana, Spain. Acta Geotech Slov 11(2):35-45 
Garrido ME, Martínez-Ibáñez V, Hidalgo C, Biase SD, Tomás R (2020) Effects of thermal gradient on limestone exposed to high temperatures. In: Li JMCC, Ødegaard H, Høien AH (eds) ISRM International Symposium Eurock 2020. International Society for Rock Mechanics and Rock Engineering Norwegian Group for Rock Mechanics, Trondheim

Gokceoglu C, Zorlu K (2004) A fuzzy model to predict the uniaxial compressive strength and the modulus of elasticity of a problematic rock. Eng Appl Artif Intell 17(1):61-72. https://doi.org/10. 1016/j.engappai.2003.11.006

Gomez-Heras M, Benavente D, Pla C, Martinez-Martinez J, Fort R, Brotons V (2020) Ultrasonic pulse velocity as a way of improving uniaxial compressive strength estimations from Leeb hardness measurements. Constr Build Mater 261:119996. https://doi.org/ 10.1016/j.conbuildmat.2020.119996

González-Gómez WS, Quintana P, May-Pat A, Avilés F, May-Crespo J, Alvarado-Gil JJ (2015) Thermal effects on the physical properties of limestones from the Yucatan Peninsula. Int J Rock Mech Min Sci 75:182-189. https://doi.org/10.1016/j.ijrmms.2014.12.010

Griffiths L, Heap MJ, Baud P, Schmittbuhl J (2017) Quantification of microcrack characteristics and implications for stiffness and strength of granite. Int J Rock Mech Min Sci 100(October):138-150. https://doi.org/10.1016/j.ijrmms.2017.10.013

Hassani FP, Scoble MJ, Whittaker BN (1980) Application of the point load index test to strength determination of rock and proposals for a new size-correction chart. In: The 21st US symposium on rock mechanics (USRMS). OnePetro, vol 1. pp 543-564

Huang YH, Yang SQ, Tian WL, Zhao J, Ma D, Zhang CS (2017) Physical and mechanical behavior of granite containing pre-existing holes after high temperature treatment. Arch Civ Mech Eng 17(4):912-925. https://doi.org/10.1016/j.acme.2017.03.007

Idris MA (2018) Effects of elevated temperatures on physical and mechanical properties of carbonate rocks in south-southern Nigeria. Min Miner Depos 12(4):20-27. https://doi.org/10.15407/ mining 12.01.020

Ioannou I, Aspinall W, Rush D, Bisby L, Rossetto T (2017) Expert judgment-based fragility assessment of reinforced concrete buildings exposed to fire. Reliab Eng Syst Saf 167(May):105-127. https://doi.org/10.1016/j.ress.2017.05.011

Jansen DP, Carlson SR, Young RP, Hutchins DA (1993) Ultrasonic imaging and acoustic emission monitoring of thermally induced microcracks in Lac du Bonnet granite. JGR Solid Earth 98(12):22231-22243. https://doi.org/10.1029/93JB01816

Kahraman S, Gunaydin O, Fener M (2005) The effect of porosity on the relation between uniaxial compressive strength and point load index. Int J Rock Mech Min Sci 42(4):584-589. https://doi.org/ 10.1016/j.ijrmms.2005.02.004

Karakurt I, Aydin G, Aydiner K (2012) A study on the prediction of kerf angle in abrasive waterjet machining of rocks. Proc Inst Mech Eng Part B J Eng Manuf 226(9):1489-1499. https://doi.org/10. $1177 / 0954405412454395$

Keshavarz M, Pellet FL, Loret B (2010) Damage and changes in mechanical properties of a gabbro thermally loaded up to $1,000^{\circ} \mathrm{C}$. Pure Appl Geophys 167(12):1511-1523. https://doi.org/10.1007/ s00024-010-0130-0

Kohno M, Maeda H (2012) Relationship between point load strength index and uniaxial compressive strength of hydrothermally altered soft rocks. Int J Rock Mech Min Sci 50:147-157

Kompatscher M (2004) Equotip-rebound hardness testing after D. Leeb. In: Proceedings, conference on hardness measurements theory and application in laboratories and industries, vol 1. pp 1-12

Kumari WGP, Ranjith PG, Perera MSA, Chen BK, Abdulagatov IM (2017) Temperature-dependent mechanical behaviour of Australian Strathbogie granite with different cooling treatments. Eng Geol. https://doi.org/10.1016/j.enggeo.2017.09.012
Lewis CD (1982) Industrial and business forecasting methods: a practical guide to exponential smoothing and curve fitting. Butterworth-Heinemann

Lion M, Skoczylas F, Ledésert B (2005) Effects of heating on the hydraulic and poroelastic properties of bourgogne limestone. Int J Rock Mech Min Sci 42(4):508-520. https://doi.org/10.1016/j. ijrmms.2005.01.005

Liu S, Xu J (2014) Mechanical properties of Qinling biotite granite after high temperature treatment. Int J Rock Mech Min Sci 71:188-193. https://doi.org/10.1016/j.ijrmms.2014.07.008

Mao XB, Zhang L, Li TZ, Liu HS (2009) Properties of failure mode and thermal damage for limestone at high temperature. Min Sci Technol 19(3):290-294. https://doi.org/10.1016/S1674-5264(09) 60054-5

Martínez-Ibáñez V, Benavente D, Hidalgo Signes C, Tomás R, Garrido ME (2020a) Temperature-induced explosive behaviour and thermo — chemical damage on pyrite—bearing limestones : causes and mechanisms. Rock Mech Rock Eng. https://doi.org/10.1007/ s00603-020-02278-x

Martínez-Ibáñez V, Garrido ME, Hidalgo Signes C, Tomás R (2020b) Study of explosive behaviour at high temperatures on limestones from a road tunnel in Spain. In: Li JMCC, Ødegaard H, Høien AH (eds) ISRM International Symposium Eurock 2020. International Society for Rock Mechanics and Rock Engineering Norwegian Group for Rock Mechanics, Trondheim

Martínez-Ibáñez V, Garrido ME, Hidalgo-Signes C, Basco A, Miranda T, Tomás R (2021a) Thermal effects on the drilling performance of a limestone: relationships with physical and mechanical properties. Appl Sci. https://doi.org/10.3390/app11073286

Martínez-Ibáñez V, Garrido ME, Hidalgo Signes C, Tomás R (2021b) Micro and macro-structural effects of high temperatures in Prada limestone: Key factors for future fire-intervention protocols in Tres Ponts Tunnel (Spain). Construct Build Mater 286:122960. https://doi.org/10.1016/j.conbuildmat.2021.122960

Meng QB, Wang CK, Liu JF, Zhang MW, Lu MM, Wu Y (2020) Physical and micro-structural characteristics of limestone after high temperature exposure. Bull Eng Geol Env 79(3):1259-1274. https://doi.org/10.1007/s10064-019-01620-0

Meulenkamp F, Alvarez Grima M (1999) Application of neural networks for the prediction of the unconfined compressive strength (UCS) from Equotip hardness. Int J Rock Mech Min Sci 36(1):29_ 39. https://doi.org/10.1016/S0148-9062(98)00173-9

O'Rourke JE (1989) Rock index properties for geoengineering in underground development. Min Eng (littleton, Colorado) 41(2):106-109

Ovejero M, Queralt I, De la Fuente C (2005) Petrography and hydric characterization of the quarry material of the varieties of Borriol Stone (Castellon). Materiales de Construccion, 55 no 278(c), 41-54. Retrieved from http://materconstrucc.revistas.csic.es. Accessed Nov 2016

Ozguven A, Ozcelik Y (2014) Effects of high temperature on physicomechanical properties of Turkish natural building stones. Eng Geol 183:127-136. https://doi.org/10.1016/j.enggeo.2014.10.006

Pomiès MP, Menu M, Vignaud C (1999) Tem observations of goethite dehydration: application to archaeological samples. J Eur Ceram Soc 19(8):1605-1614. https://doi.org/10.1016/s0955-2219(98) 00254-4

Rabat A, Cano M, Tomás R, Tamayo E, Alejano LR (2020) Evaluation of strength and deformability of soft sedimentary rocks in dry and saturated conditions through needle penetration and point load tests: a comparative study. Rock Mech Rock Eng 53(6):27072726. https://doi.org/10.1007/s00603-020-02067-6

Rosengren KJ, Jaenger JC (1968) The mechanical properties of an interlocked low-porosity aggregate. Geotechnique 18:317-326 
Sabatakakis N, Koukis G, Tsiambaos G, Papanakli S (2008) Index properties and strength variation controlled by microstructure for sedimentary rocks. Eng Geol 97(1-2):80-90. https://doi.org/10. 1016/j.enggeo.2007.12.004

Şahin M, Ulusay R, Karakul H (2020) Point load strength index of half-cut core specimens and correlation with uniaxial compressive strength. Rock Mech Rock Eng 53(8):3745-3760. https://doi.org/ 10.1007/s00603-020-02137-9

Saroglou H, Tsiambaos G (2007) Classification of anisotropic rocks. In: 11th ISRM congress. OnePetro, vol 1. pp 191-196

Singh VK, Singh DP (1993) Correlation between point load index and compressive strength for quartzite rocks. Geo tech Geol Eng 11:269-272

Singh VK, Singh D, Singh TN (2001) Prediction of strength properties of some schistose rocks from petrographic properties using artificial neural networks. Int J Rock Mech Min Sci 38(2):269-284. https://doi.org/10.1016/S1365-1609(00)00078-2

Singh R, Umrao RK, Ahmad M, Ansari MK, Sharma LK, Singh TN (2017) Prediction of geomechanical parameters using soft computing and multiple regression approach. Measurement 99:108119. https://doi.org/10.1016/j.measurement.2016.12.023

Sirdesai NN, Singh TN, Ranjith PG (2017) Thermal alterations in the poro-mechanical characteristic of an Indian sandstone-a comparative study. Eng Geol 226:208-220. https://doi.org/10.1016/j. enggeo.2017.06.010

Sonmez H, Tuncay E, Gokceoglu C (2004) Models to predict the uniaxial compressive strength and the modulus of elasticity for Ankara Agglomerate. Int J Rock Mech Min Sci 41(5):717-729. https:// doi.org/10.1016/j.ijrmms.2004.01.011

Sonmez H, Gokceoglu C, Medley EW, Tuncay E, Nefeslioglu HA (2006) Estimating the uniaxial compressive strength of a volcanic bimrock. Int J Rock Mech Min Sci 43(4):554-561. https://doi.org/ 10.1016/j.ijrmms.2005.09.014

Sulukcu S, Ulusay R (2001) Evaluation of the block punch index test with particular reference to the size effect, failure mechanism and its effectiveness in predicting rock strength. Int J Rock Mech Min Sci 38:1091-1111

Thuro K, Plinninger RJ, Zah S, Schutz S (2001) Scale effects in rock strength properties. Part 2: point load test and point load strength index. In: Särkkä P, Eloranta P (eds) Rock mechanics-a challenge for society, $\mathrm{p} 881$. Proceedings of the ISRM regional symposium Eurock, pp 175-180

Tomás R, Cano M, Pulgarín LF, Brotóns V, Benavente D, Miranda T, Vasconcelos $G$ (2021) Thermal effect of high temperatures on the physical and mechanical properties of a granite used in UNESCO World Heritage Sites in North Portugal. J Build Eng 43:1-16. https://doi.org/10.1016/j.jobe.2021.102823

Török A, Hajpál M (2005) Effect of temperature changes on the mineralogy and physical properties of sandstones a laboratory study. Restor Build Monum Bauinstandsetzen Und Baudenkmalpflege 11(4):1-8

Tugrul A, Zarif IH (1999) Correlation of mineralogical and textural characteristics with engineering properties of selected granitic rocks from Turkey. Eng Geol 51:303-317

Vagnon F, Colombero C, Colombo F, Comina C, Ferrero AM, Mandrone G, Vinciguerra SC (2019) Effects of thermal treatment on physical and mechanical properties of Valdieri Marble-NW Italy. Int J Rock Mech Min Sci 116:75-86. https://doi.org/10.1016/j. ijrmms.2019.03.006

Vagnon F, Colombero C, Comina C, Ferrero AM, Mandrone G, Missagia R, Vinciguerra SC (2021) Relating physical properties to temperature-induced damage in carbonate rocks. Geotech Lett 11(2):1-11. https://doi.org/10.1680/jgele.20.00122
Verwaal W, Mulder A (1993) Estimating rock strength with the Equotip hardness tester. Int J Rock Mech Min Sci Geomech Abstr 30(6):659-662

Viles H, Goudie A, Grab S, Lalley J (2011) The use of the Schmidt Hammer and Equotip for rock hardness assessment in geomorphology and heritage science: a comparative analysis. Earth Surf Proc Land 36(3):320-333. https://doi.org/10.1002/esp.2040

Villarraga CJ, Gasc-Barbier M, Vaunat J, Darrozes J (2018) The effect of thermal cycles on limestone mechanical degradation. Int J Rock Mech Min Sci 109:115-123. https://doi.org/10.1016/j.ijrmms. 2018.06.017

Wang F, Frühwirt T, Konietzky H, Zhu Q (2019) Thermo-mechanical behaviour of granite during high-speed heating. Eng Geol 260:105258. https://doi.org/10.1016/j.enggeo.2019.105258

Wong LNY, Zhang Y, Wu Z (2020) Rock strengthening or weakening upon heating in the mild temperature range? Eng Geol 272:105619. https://doi.org/10.1016/j.enggeo.2020.105619

Wu G, Wang Y, Swift G, Chen J (2013) Laboratory investigation of the effects of temperature on the mechanical properties of sandstone. Geotech Geol Eng 31(2):809-816. https://doi.org/10.1007/ s10706-013-9614-x

Yang J, Fu LY, Zhang W, Wang Z (2019) Mechanical property and thermal damage factor of limestone at high temperature. Int $\mathbf{J}$ Rock Mech Min Sci. https://doi.org/10.1016/j.ijrmms.2019.03.012

Yesiloglu-Gultekin N, Gokceoglu C, Sezer EA (2013) Prediction of uniaxial compressive strength of granitic rocks by various nonlinear tools and comparison of their performances. Int J Rock Mech Min Sci 62:113-122. https://doi.org/10.1016/j.ijrmms.2013.05. 005

Yilmaz NG (2013) The influence of testing procedures on uniaxial compressive strength prediction of carbonate rocks from Equotip hardness tester (EHT) and proposal of a new testing methodology: hybrid dynamic hardness (HDH). Rock Mech Rock Eng. https:// doi.org/10.1007/s00603-012-0261-y

Ylmaz I, Sendr H (2002) Correlation of Schmidt hardness with unconfined compressive strength and Young's modulus in gypsum from Sivas (Turkey). Eng Geol 66(3-4):211-219. https://doi.org/10. 1016/S0013-7952(02)00041-8

Yüksek S (2019) Mechanical properties of some building stones from volcanic deposits of mount Erciyes (Turkey). Mater Constr 69:187. https://doi.org/10.3989/mc.2019.04618

Zhang W, Lv C (2020) Effects of mineral content on limestone properties with exposure to different temperatures. J Pet Sci Eng 188:106941. https://doi.org/10.1016/j.petrol.2020.106941

Zhang LY, Mao XB, Lu AH (2009) Experimental study on the mechanical properties of rocks at high temperature. Sci China Ser E Technol Sci 52(3):641-646. https://doi.org/10.1007/ s11431-009-0063-y

Zhang W, Sun Q, Hao S, Geng J, Lv C (2016) Experimental study on the variation of physical and mechanical properties of rock after high temperature treatment. Appl Therm Eng 98:1297-1304. https://doi.org/10.1016/j.applthermaleng.2016.01.010

Zorlu K, Gokceoglu C, Ocakoglu F, Nefeslioglu HA, Acikalin S (2008) Prediction of uniaxial compressive strength of sandstones using petrography-based models. Eng Geol 96(3-4):141-158. https:// doi.org/10.1016/j.enggeo.2007.10.009

Publisher's Note Springer Nature remains neutral with regard to jurisdictional claims in published maps and institutional affiliations. 